\title{
İstihdam Yaratmayan Ekonomik Büyüme: Türkiye İçin Okun Yasası Çerçevesinde Ekonometrik Bir Analiz
}

\author{
Hüseyin USLU*
}

ÖZ

Bu çalışmada, Okun Yasasının Türkiye ekonomisinde geçerliliği; 1923-1971, 1972-2019 ve 1923-2019 dönemleri için analiz edilmiştir. Serilerin durağanlığı Carrion-i-Silvestre vd. (2009) çoklu yapısal kırılmalı birim kök testi ile incelenmiş ve serilerin I(1) oldukları belirlenmiştir. Seriler arasındaki eşbütünleşme ilişkileri de Maki (2012) çoklu yapısal kırılmalı eşbütünleşme testi ile incelenmiş ve seriler arasında eşbütünleşme ilişkisinin olduğu bulunmuştur. Regresyon katsayıları DOLS, FMOLS ve CCR yöntemleriyle tahmin edilmiş ve Okun Yasasının Türkiye ekonomisinde 1923-1971 döneminde güçlü, 1923-2019 döneminde zayıf formda geçerli olduğu, 1972-2019 döneminde ise İstihdam Yaratmayan Ekonomik Büyüme Teorisinin geçerli olduğu tespit edilmiştir. Buna göre 1923-1971 döneminde $\% 5,3$ 'ün üzerindeki her \%1 puanlık ekonomik büyüme, işsizlik oranını \%0.33 puan, 1923-2019 döneminde ise $\% 4,9$ 'un üzerinde gerçekleşen her \%1 puanlık ekonomik büyüme işsizlik oranını $\% 0.03$ birim azaltmıştır. 19722019 döneminde ise $\% 4,4$ 'ün üzerindeki her \%1 puanlı ekonomik büyüme, işsizliği \%0.63 puan artırmıştır. Yapılan VECM nedensellik testi sonuçlarına göre; Türkiye ekonomisinde işsizlik oranı ile ekonomik büyüme arasında kısa dönemde herhangi bir nedensellik ilişsisi tespit edilemezken, uzun dönemli nedensellik ilişkileri belirlenmiştir.

Anahtar Kelimeler: Okun Yasası, İstihdam Yaratmayan Ekonomik Büyüme, Çoklu Yapısal Kırılmalı Birim Kök Testi, Çoklu Yapısal Kırılmalı Eşbütünleşme Testi.

JEL Sinıflandırması: E24, F43, J24.

\section{Jobless Economic Growth: An Econometric Analysis for Turkey in the Framework of Okun Law}

\begin{abstract}
In this study, the validity of Okun Law in the economy of Turkey is analyzed for 1923-1971, 1972-2019 and 1923-2019 periods. Stationarity of the series is examined by Carrion-i-Silvestre et al. (2009) unit root test with multiple structural break and it is determined that the series are $\mathrm{I}(1)$. Cointegration relationships between the series are examined by Maki (2012) cointegration test with multiple structural breaks and it is found that there is a cointegration relationship between the series. Regression coefficients are estimated by the methods of DOLS, FMOLS and CCR and it is determined that Okun Law is strongly valid in 1923-1971 period in Turkey's economy, weakly valid in the period of 1923-2019 while Jobless Growth Theory is valid for 1972-2019 period. According to these results, every 1\% unit of economic growth above $5.3 \%$ in the period of $1923-1971$ decreased the unemployment rate by $0.33 \%$ units and every $1 \%$ unit of economic growth above $4.9 \%$ in the period of $1923-2019$ reduced the unemployment rate by $0.03 \%$ units. In the period of 1972-2019, every $1 \%$ unit of economic growth above $4.4 \%$ increased unemployment rate by $0.63 \%$. According to VECM causality test results; while there aren't any causal relationship between economic growth and unemployment in the short-term, there are long-term causal relationship.
\end{abstract}

Keywords: Okun Law, Jobless Economic Growth Theory, Unit Root Test with Multiple Structural Breaks, Cointegration Test with Multiple Structural Breaks.

JEL Classification: E24, F43, J24.

Geliş Tarihi / Received: 11.03.2019 Kabul Tarihi / Accepted: 20.08.2019

\footnotetext{
* Erciyes Üniversitesi, İ̈BF, İktisat Bölümü, h.uslu80@ hotmail.com, ORCID: 0000-0002-2642-1175
} 


\section{GíRİş}

Ekonomik büyüme; ülkelerde geliri artıran, genel olarak işsizliği azaltan, yurttaşların refah seviyesini yükselten en önemli ekonomik olgu olup, bütün hükümetlerin öncelikli hedeflerindendir. Ekonomik büyümenin azalması; işsizliği ve kişi başına düşen milli geliri azaltarak, ülkelerde yoksulluğu ve refah seviyesi azalmasını birlikte getirmekte, bu durum uzun süre devam ettiğinde ülkelerde iktidar ve/veya yönetim sistemi ${ }^{1}$ değișiklikleri yaşanabilmektedir. Literatürde; işsizlik oranı ile enflasyon oranının toplanmasıyla oluşturulan ve Hoşnutsuzluk Endeksi adı verilen bir endeksin var olması da toplumda en fazla hoşnutsuzluk oluşturan ekonomik sorunların; işsizlik ve enflasyon olduğunu göstermektedir (Işık ve Öztürk Çetenek, 2018). İşsizlik oranları çok arttı̆̆ında, ülkelerde ekonomik ve sosyal olaylar ${ }^{2}$ meydana gelebilmekte, ahlaki çöküntü (Levin ve Wright, 2002), boşanmalar (Lester, 1996) ve intihar olayları artabilmektedir (Agerbo, 2003).

Türkiye ekonomisi de yüksek işsizlik sorunu ile baş etmeye çalışmakta olup, 2001 krizine kadar \%6-8 aralığında dalgalanan işsizlik oranı (Güney, 2009), bu tarihten sonra \%10'un üzerine çıkmış, 2008 krizinin etkisiyle Şubat 2009'da \%16.2'yi görmüş, 2009 yılı genelinde \%13.1 olarak gerçekleşmiştir (Yanbaşlı, 2014). 2010 yılından itibaren ekonomi hızla büyümeye başlamışsa da işsizlik bir türlü tek haneli sayılarda tutulamamıştır. 2018 yılında Türkiye'de işsizlik tekrar artmaya başlamış, 2019 yılı ilk iki aylık döneminde ortalama \%14.7 olarak gerçekleşmiştir (TUIK, 2019).

İşsizlik oranlarını azaltabilmek için ülkelerin yeni yatırımlar yapmaları, doğrudan yabancı yatırım (DYY) çekmeleri, yeni pazarlar bulmaları ve ekonomik büyümelerini artırarak, yurttaşlarının harcanabilir gelir düzeylerini artırmaları gerekmektedir. Ancak ekonomik büyüme, her zaman istihdam artışını beraberinde getiremeyebilmektedir. Bu durum ekonomide; İstihdam Yaratmayan Ekonomik Büyüme Teorisinin doğmasına neden olmuştur (Abdioğlu ve Albayrak, 2017). Türkiye ekonomisi 2018 yılında \%7.2 büyümüş olmasına karşın, günümüzde işsizlik hızla artmaktadır. Benzer bir durum 2010-2011 döneminde de yaşanmıştır. 2011 yılında ekonomi \%11.1 büyümüş, ama 2008 kriziyle artan işsizlik bir türlü azaltılamamıştır. Dolayısıyla bu konu, Türkiye açısından büyük önem taşımaktadır.

Yeldan ve Ercan (2011) Türkiye'de yaşanan bu durumun nedenlerinin; emek piyasasında hüküm süren aşırı düzenlemeler, vergi yükünün yüksekliği, kırsal bölgelerden kent merkezlerine doğru yaşanan aşırı göç, büyümenin dış borçlanma ve yabancı sermaye hareketlerine bağımlı olarak gerçekleşiyor olması olduğunu ifade etmiştir. Özdemir ve Yıldırım (2015) ise istihdam yaratmayan ekonomik büyümenin sadece Türkiye'ye özgü bir durum değil, küresel bir makroekonomik sorun olduğunu ifade etmiştir.

Bu çalışmada; Türkiye'de istihdam yaratmayan ekonomik büyüme olgusunun geçerliliği, 1923-2019 dönmemi için teorik ve ekonometrik olarak analiz edilmiştir. Çalışmanın girişi takip eden ikinci bölümünde; ekonomik büyüme ile işsizlik arasındaki ilişkiler incelenmiş, istihdam yaratmayan ekonomik büyüme olgusu teorik olarak ele alınmıştır. Üçüncü bölümde; Türkiye'de ekonomik büyüme ve işsizlik verileri, grafikler yardımıyla analiz edilmiştir. Dördüncü bölümde;

\footnotetext{
1 1929-1933 döneminde etkili olan Büyük Bunalım sonucunda Almanya'da Hitler, İtalya'da Mussolini gibi baskıcı yönetimler iktidara gelmiş, Japonya' da militarist ve milliyetçi yönetim anlayışının yönetimde egemen olmasına neden olmuştur (Yıldırım, Karaman ve Taşdemir, 2009: 13-14; Dünya Bülteni, 2011).

${ }^{2}$ Buna güzel bir örnek; Aralık 2010 yılında Tunus’ta başlayıp, bütün Kuzey Afrika ve Ortadoğu ülkelerini etkisi altına alan, Suriye, Mısır ve diğer bazı ülkelerde etkileri hala devam eden Arap Baharı olaylarının arkasında; Tunus'ta yaşanan aşırı işsizlik olduğu söylenebilir. Bunun nedeni olarak; üniversite mezunu, 27 yaşında işsiz bir genç olan Muhamed Bouazizi'nin ailesine bakabilmek için seyyar satıcılık yaptığı tezgâhının Tunus zabıta güçleri tarafından parçalanması ve kendisinin de darp edilmesi üzerine kendisini yakarak intihar etmesi örnek verilebilir (Rashad, 2011). Benzer olaylar; genç işsizlik oranının \%60'lara dayandığı Bosna Hersek’te, genç işsizlik oranının \%50'lerde olduğu Fransa'da (O'Kane, 2011) ve Yunanistan'da (Bell ve Blanchflower, 2015) da yaşanmıştır.
} 
konuyla ilgili literatür özeti sunulmuş, beşinci bölümde ekonometrik analiz gerçekleştirilmiştir. Altıncı bölümdeki sonuç ve değerlendirmelerle çalışma tamamlanmıştır. Çalışmanın; incelenen konu, kullanılan veri seti ve analiz yöntemleri itibariyle literatüre ve ülke ekonomisine bir katkı sağlaması beklenmektedir.

\section{TEORIKK ÇERÇEVE}

Klasik İktisatçlar ekonominin her zaman tam istihdam düzeyinde dengede olduğunu kabul ederek, işsizlik sorunun varlığını kabul etmeyip, buna çözüm arama gereği duymazken, Keynes (1936), tam istihdamın ekonomide bir istisna olduğunu, asıl olanın ekonomilerin eksik istihdamda dengede olması olduğunu ifade etmiştir. Keynes ile başlayan bu akımda ekonomistler işsizlik sorunun varlığını kabul etmişler ve buna çözüm önerileri geliştirmeye çalışmışlardır (Blinder, 2010).

Ekonomik büyüme ile işsizlik arasındaki ilişkileri ekonometrik olarak ilk inceleyen araştırmacı Arthur Okun olmuştur. Bundan dolayı literatüre Okun Yasası olarak giren bu çalışmasında Okun (1962), ABD’nin 1948-1960 dönmemi işsizlik oranı ve ekonomik büyüme verilerini kullanarak, potansiyel (ortalama) ekonomik büyüme oranının üzerindeki her 1 puanlık büyüme artışının, işsizlik oranını 0,5 puan azalttı̆̆ını belirlemiştir (Uslu, 2018: 1517). Okun (1962) bu çalışmasında ABD'nin ortalama büyüme oranını \%2.25 olarak belirlemiş ve bu oranı aşan büyümelerin işsizliği azaltacağını, potansiyel büyümenin altında kalacak büyüme oranlarının ise ABD'de işsizliği artıracağını ortaya koymuştur. $\mathrm{Bu}$ durum Denklem (1) yardımıyla açıklanabilir:

$$
\Delta u=-0.5 *(y-2.25)
$$

Burada $u$; işsizlik oranını (unemployment rate), $y$; cari dönem büyüme oranını, 2.25; 1948- 1960 döneminde ABD’nin ortalama ekonomik büyüme oranını göstermektedir. Buradaki katsayı $(-0,5)$ ve ortalama büyüme oran1, ülkeler ve inceleme dönemleri arasında farklılık gösterebilecektir. Neely (2010) 30 OECD ülkesinde 2008:Q2-2019:Q3 öneminde ekonomik büyümedeki azalışların, işsizliği değişen oranlarda artırdığını; Alamro ve Al-dala'ien (2016) Ürdün için yaptığı analizde; milli gelirdeki 1 puanlık artışının, işsizliği 0.013 puan azalttığını; Yıldırım, Karaman ve Taşdemir (2009) Türkiye'de 1975-1995 döneminde ortalama büyüme oranının \%4,3 olduğunu, bu oranı aşan her 1 puanlık ekonomik büyümenin işsizliği 0.13 puan azalttığını belirlemiştir. Diğer yandan Muratoğlu (2011) Türkiye'de 2000:Q1-2010:Q3 döneminde, Yüksel (2016), Rusya'da 1992-2014 döneminde, Yazıcı (2018) Türkiye'de 19602015 döneminde, Eğri (2018) Misır ekonomisinde 1970-2016 döneminde Okun Yasası'nın geçerli olmadığı sonucuna ulaşmıştır. Bu durum, ekonomide istihdam yaratmayan ekonomik büyüme teorisini (Jobless Economic Growth Theory: JEGT) gündeme getirmiştir (The Economist, 2010; World Bank, 2018). Bu teoriye göre; bazı dönemlerde ekonomik büyüme; verimlilik artışı ya da kapasite kullanım oranı artışı yollarıyla gerçekleşebilmektedir (Murat ve Yılmaz-Eser, 2013: 106). Bu durumda, çalışan sayısı artmasa bile mevcut işgücünün daha etkin çalıştırılması ya da otomasyon teknolojilerinin kullanılmasıyla birlikte, emek yoğun üretim stratejilerinden, sermaye yoğun üretim stratejilerine geçilmesi nedeniyle, yeni işgücü istihdam edilmeden (işsizlik oranı azalmadan) da ekonomik büyüme gerçekleşebilmektedir (Léautier ve Hanson, 2013: 5). Máté (2010), OECD ülkeleri için yaptığı araştırmada, bu ülkelerde JEGT'nin değil Job-Low Growth Theory'nin (JLGT) (Düşük İstihdam Yaratan Ekonomik Büyüme Teorisinin) geçerli olduğunu tespit etmiştir. Bu teoriye göre; ülkeler sadece yeni işgücü istihdamı ile büyümezler, mevcut işgücünün daha verimli hale getirilmesi (verimlilik artışı), daha yoğun çalıştırılması (kapasite kullanım oranı artışı), emek yoğun üretim stratejileri yerine sermaye yoğun üretim stratejilerinin kullanımı ile de büyüyebilmektedir. 
Öte yandan çıktıdaki (reel milli gelirdeki) değişimler ile işsizlik oranındaki değişimler arasında farklı etkileşimler söz konusu olabilmektedir. Birincisi; çıktı arttığında, bireylerin talep yapısı değişecek, iç talep artacaktır. Bu durum, şirketlerin satışlarını ve karlılığını artırarak, üretimi ve istihdamı uyarabilecektir (Tejani, 2016: 845-846). İkincisi; çıktıdaki artışa bağlı olarak reel ücretler aratabilecek, bu da Etkin Ücret Teorisi gereği işgücü verimliliğini yükseltebilecektir. Artan verimliliğe bağlı olarak, yeni istihdama gerek duyulmaksızın çıktı düzeyi yüksek kalmaya devam edebilecektir (Kigabo ve Kamanzi, 2018: 12). Üçüncü muhtemel etkiyse; çıktı artışına bağlı olarak gerçekleşen reel ücret ve verimlilik artışı, işgücünün marjinal verimliliğini artıracağı için firmaları daha fazla işgücü istihdam etmeye yönlendirerek, işsizliğin azalmasına katkı sağlayabilecektir (Murat ve Yılmaz-Eser, 2013: 108). Bu etkilerden hangilerinin geçerli olduğu, yapılacak ampirik çalışmalar sonucunda tespit edilebilmektedir.

\section{TÜRKIYYE EKONOMISIINDE EKONOMIK BÜYÜME VE İSSIZLLIKK}

Türkiye, Cumhuriyetin ilanından sonra 1931 y1lına kadar liberal ekonomi politikaları uygulamış, ekonomik büyümeyi özel sektör eliyle gerçekleştirmeyi amaçlamıştır. Ancak 1929'da başlayan ve etkileri 1933 yılına kadar devam eden Büyük Bunalım, zaten zayıf olan özel sektörün bu kalkınma hamlelerini gerçekleştirmelerini iyice imkânsız hale getirmiştir. Bunun üzerine 1931 yılında Devletçilik İlkesi kabul edilmiş ve 1933'ten itibaren temel ekonomik yatırımlar devlet eliyle yapılmaya başlanmıştır. 1939 yılında II. Dünya Savaşı başlayana kadar yüksek oranda büyüyen Türkiye ekonomisi, bu savaşın etkisiyle önemli ölçüde küçülmüştür. Sonrasında yapılan atılımlarla 1946 yılında kendi uçak ve traktörünü üretmeyi başaran ülke, önemli ölçüde büyümeye başlamıştır. 1950-1960 Demokrat Parti iktidarı ile birlikte önemli ölçüde liberal ekonomi politikaları uygulamaya başlayan Türkiye, 1960, 1971, 1980 askeri darbeleri, 28 Şubat 1997 postmodern askeri darbesi ve 2016 askeri darbe girişimlerinden, 1973-1976 petrol krizlerinden, 1974 Kıbrıs Barış Harekâtı ve devamında gelen ABD ambargosundan büyük zararlar görmüştür. Ayrıca 1994, 2001 ve 2008 ekonomik krizleri de ülkenin ekonomik büyümesini azaltan faktörler olmuştur. Bunun yanında 24 Ocak 1980 dışa açılma kararları ile ekonomik, 1989 tarihli 32 Sayılı karar ile finansal liberalizasyon gerçekleştirilmiş, 1986' da Borsa İstanbul (o zamanki ismiyle İstanbul Menkul Kıymetler Borsası) faaliyete başlamış, Ocak 1996'da Avrupa Birliği ile Gümrük Birliği anlaşması devreye girmiştir. Bunlar da ekonomik büyümeyi destekleyen etmenler olmuştur. Türkiye'nin 1948 yılı sabit fiyatlarıyla hesaplanmış 1923-2019 dönemi ekonomik büyüme oranları Grafik 1 yardımıyla incelenebilir.

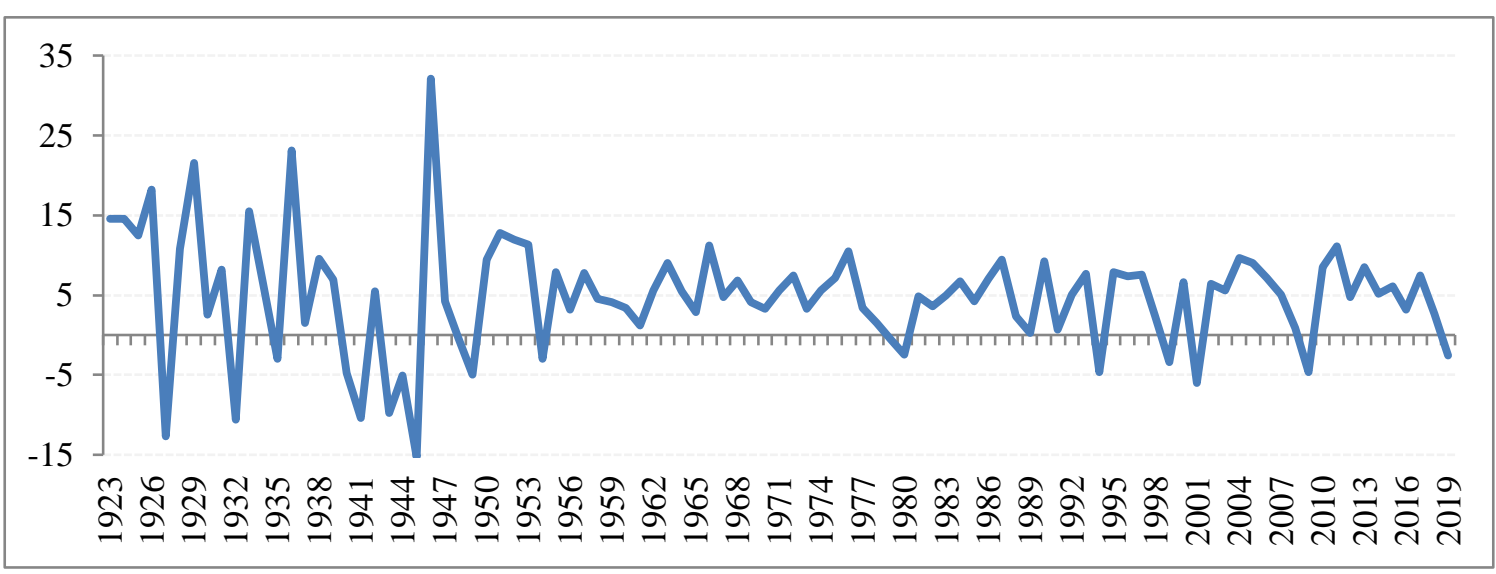

Grafik 1: Türkiye'nin Ekonomik Büyüme Oranları (\%)

Kaynak: TÜİK (2014), World Bank (2019) ve Sabah (2019). 2019 yılı verileri ilk 3 aylık dönemi kapsamaktadır. 
Grafik 1'den görüldüğü gibi; 1923-1950 dönemi ekonomik büyüme oranının önemli ölçüde dalgalandığı ve genelde yüksek olduğu bir dönemdir. 1923-1929 dönemi ortalama ekonomik büyüme oranı \%11,3 iken, Büyük Buhranın etkisiyle ekonomi 1932 yılında \%10,6 küçülmüştür. 1933 'te baz etkisiyle $\% 15.5$ büyüse de 1935 'te $\% 3$ küçülmüş, 1936 'da yine baz etkisiyle \%23.1 büyümüştür. II. Dünya Savaşının etkisiyle 1940'ta \%4.8, 1941'de \%10.4, 1943 'te $\% 9.8,1944$ 'te $\% 5.1$ ve 1945 'te $\% 15.3$ küçülen ekonomi, 1946 yılında baz etkisiyle \%32.1 oranında büyümüştür. 1930-1949 dönemi ortalama büyüme oranı \%2,5'tir. 1950'den itibaren tekrar hızlanmaya başlayan ekonomik büyüme, 1950-1960 döneminde \%6,6 olarak gerçekleşmiştir. 1960 sonrası dönemde düşük ama görece daha istikrarlı bir büyüme dönemi yaşanmış olup, 1961-1979 dönemi ortalama büyüme oranı \%5,1 olarak gerçekleşmiştir. 1980 askeri darbesiyle \%2,4, 1994 krizinde \%4,6, 1999 'da \%3,3, 2001 krizinde \%5,9 küçülen ekonomi, 2002 sonrası dönemde görece yüksek bir ekonomik büyüme performansı sergilemiştir.1980-2001 dönemi ortalama büyüme oranı \%3,7 iken 2002-2008 döneminde bu oran \%6,2'ye yükselmiștir. 2008 küresel ekonomik krizinin etkisiyle 2009 yilında \%4,7 küçülen ekonomi, 2010'da \%8,4, 2011 'de \%11,1 büyümüştür. 2010-2018 dönemi ortalama büyüme oran1; \%6,3'tür. 2019 y1lı ilk çeyreğinde ise ekonomi \%2,6 oranında küçülmüsşür. Türkiye' de işsizlik oranlarındaki değişimler Grafik 2 yardımıla incelenebilir.

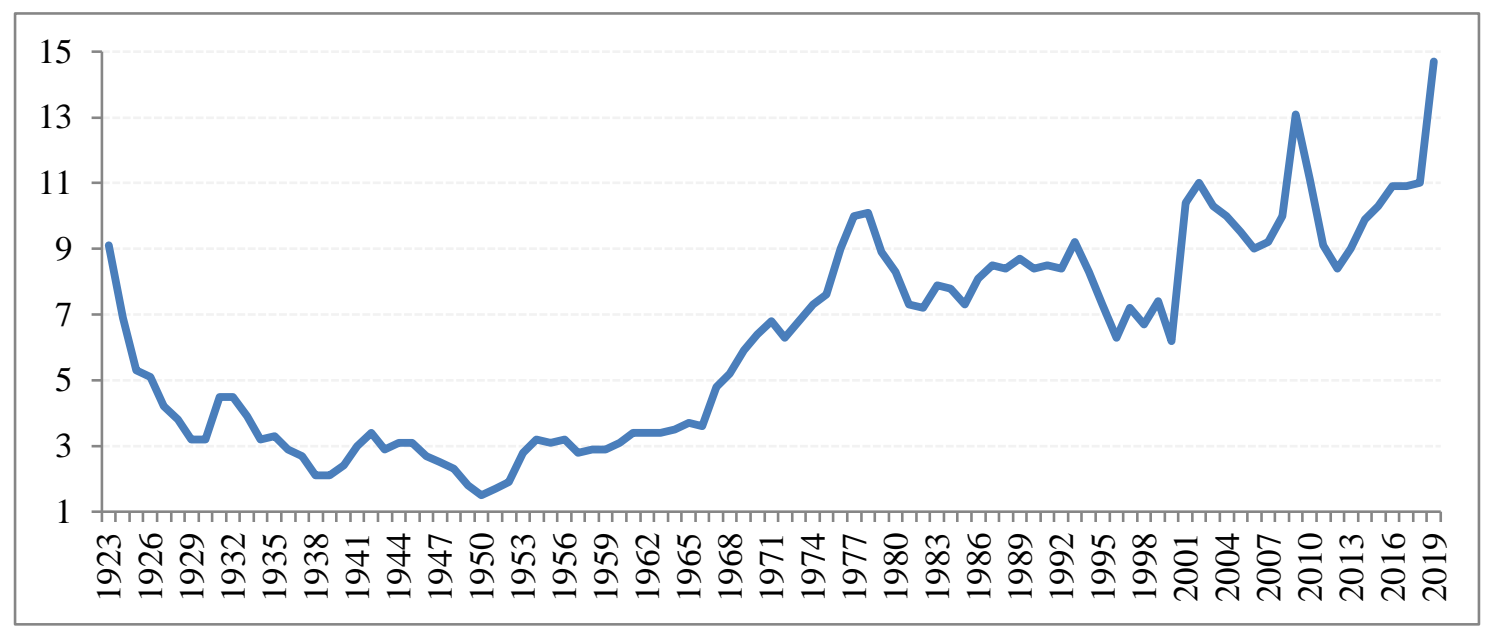

Grafik 2: Türkiye'de İşsizlik Oranları (\%)

Kaynak: Güney (2009), Yanbaşlı (2014) ve TUIKK (2019). 2019 yılı verileri ilk 3 aylık dönemi kapsamaktadır.

Grafik 2'ye bakıldığında; Cumhuriyetin ilanında sonra gerçekleştirilen hızlı ekonomik atılımlar sayesinde işsizlik oranının hızla düştüğü, 1968 yılına kadar ortalama \%3,4 olduğu görülmektedir. 1971 askeri müdahalesi, 1973 ve 1976 petrol krizleri, 1974 Kıbrıs Barış Harekâtı nedeniyle ülkeye uygulanan ambargo ve 1977-1980 dönemindeki yaygın sokak olayları nedeniyle işsizlik oranları önemli ölçüde artmış, 1969-2000 döneminde ortalama \%7,7 olarak gerçekleşmiştir. 2001 kriziyle birlikte artan işsizlik oranları, sonrasında genel olarak \%10'un üzerinde tutunmuş, Şubat 2009'da \%16,2'ye yükselmiş, 2009 yılı genelinde \%13,1 olarak gerçekleşmiştir. Ocak 2019 ve Şubat 2019'da ise \%14,7 olarak gerçekleşmiştir. 2001-2019

\footnotetext{
${ }^{3}$ Baz etkisi; ekonominin küçüldüğü dönemi takip eden dönemde gerçekleşen büyümenin, olduğundan çok daha büyük gözükmesini ifade etmektedir. Örneğin; reel milli gelirin $100 \mathrm{TL}$ olduğu bir yılı takip eden bir yılda ekonomi \%10 küçülerek, milli gelir 90 TL ye gerilemiş olsun. Sonra bir sonraki yıl milli gelir 110 TL'ye çıksın. Ekonomi küçülmeseydi, 100'den 110'a \% 10 büyümüş olacaktı. Oysa şimdi 90'dan 110'a gelerek \%22,2 oranında büyümüş oldu. Ekonomi literatüründe bu aşırı büyümeye, baz etkisi adı verilmektedir.
} 
dönemi ortalama işsizlik oranı; \%10,4'tür. Ekonomik büyüme ile işsizlik oranları Grafik 3’te bir arada sunulmuştur.

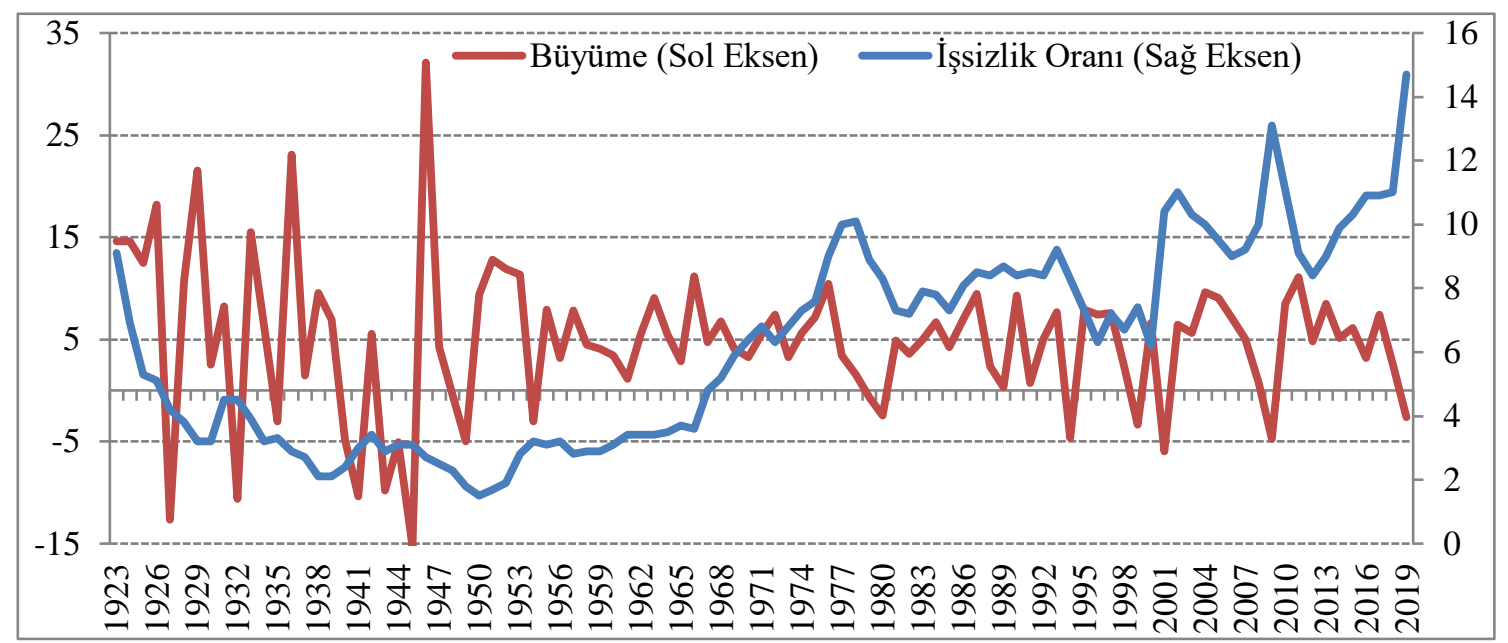

Grafik 3: Türkiye' de Ekonomik Büyüme ve İşsizlik Oranları (\%)

Kaynak: TÜIK (2014), World Bank (2019), Sabah (2019), Güney (2009), Yanbaşl1 (2014) ve TUíK (2019). 2019 yllı verileri ilk 3 aylık dönemi kapsamaktadır.

Grafik 3'e bakıldığında; 1923-1935 döneminde artan ekonomik büyüme ile birlikte işsizlik oranının, Okun Yasasına uygun biçimde azaldığı, 1950'den sonra ekonomik büyümenin ve işsizliğin eşanlı olarak arttığı (Okun Yasasının zıddı bir durum), 1977-1980 döneminde, 1994, 2001 ve 2008 krizlerinde azalan ekonomik büyümenin, Okun Yasasıyla uyumlu olarak işsizliği artırdığı, 2010 sonrası dönemde ise artan ekonomik büyümeye rağmen, Okun Yasasının zıddına, işsizlik oranının düşmediği görülmektedir. Bu grafikte 1972 yılından sonra işsizlik oranı ile ekonomik büyüme arasında bir ayrışma görüldüğü için ekonometrik analiz; 1923-2019; 19231971 ve 1972-2019 dönemleri için ayrı ayrı gerçekleştirilmiştir. Türkiye ekonomisinde 1923-1971 döneminde işsizlik oranı ile ekonomik büyüme arasındaki ilişkilerin nokta dağılım grafiğgi ve buradan üretilen eğim çizgisi Grafik 4 'te yer almaktadır.

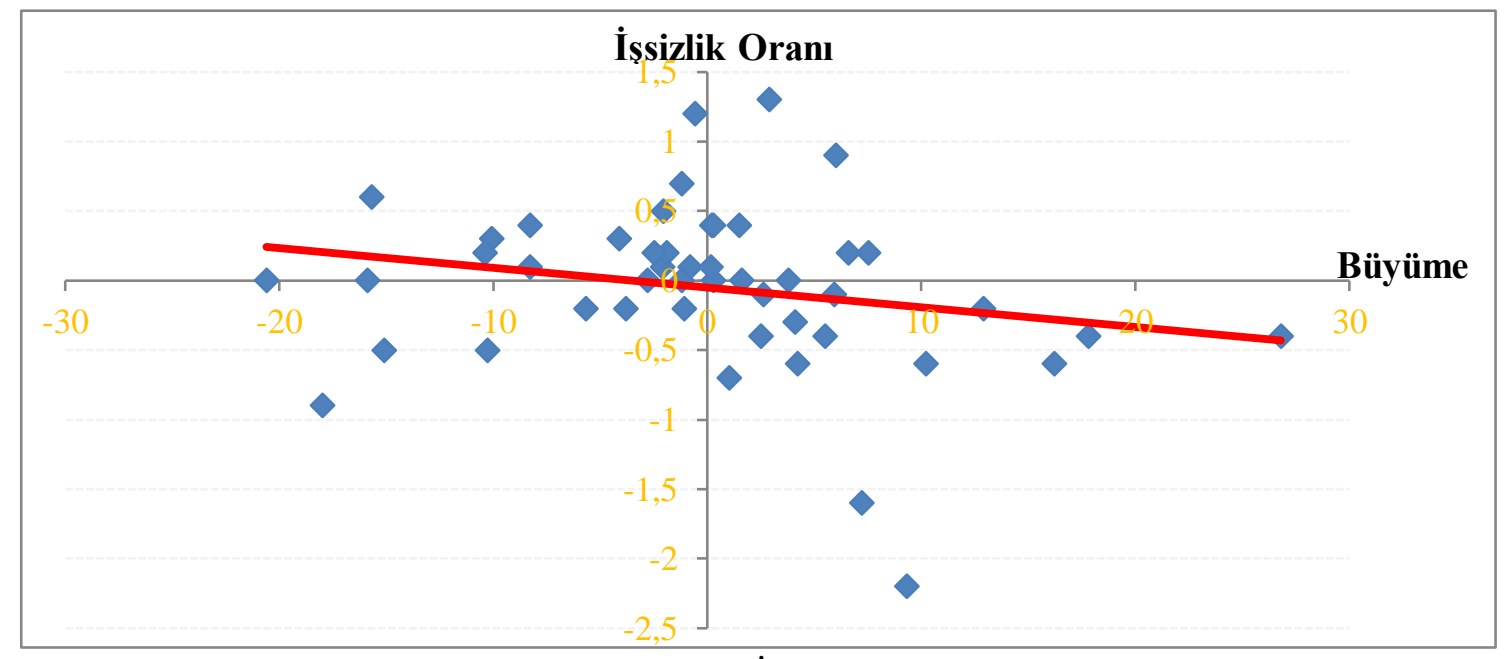

Grafik 4: Türkiye'de Ekonomik Büyüme ve İşsizlik Oranları Arasındaki ilişki (1923-1971) Kaynak: TÜiK (2014), World Bank (2019), Sabah (2019), Güney (2009), Yanbaşl1 (2014) ve TÜiK (2019). 
Grafik 4'ten de görüldüğ̈̈ üzere 1923-1971 döneminde işsizlik oranı ile ekonomik büyüme arasında zıt yönlü bir ilişki vardır. Bu durum, ilgili dönemde Türkiye ekonomisinde Okun Yasasının geçerli olduğunu ima etmektedir. Türkiye ekonomisinde 1972-2019 döneminde işsizlik oranı ile ekonomik büyüme arasındaki ilişkilerin nokta dağılım grafiği ve buradan üretilen eğim çizgisi Grafik 5'te yer almaktadır.

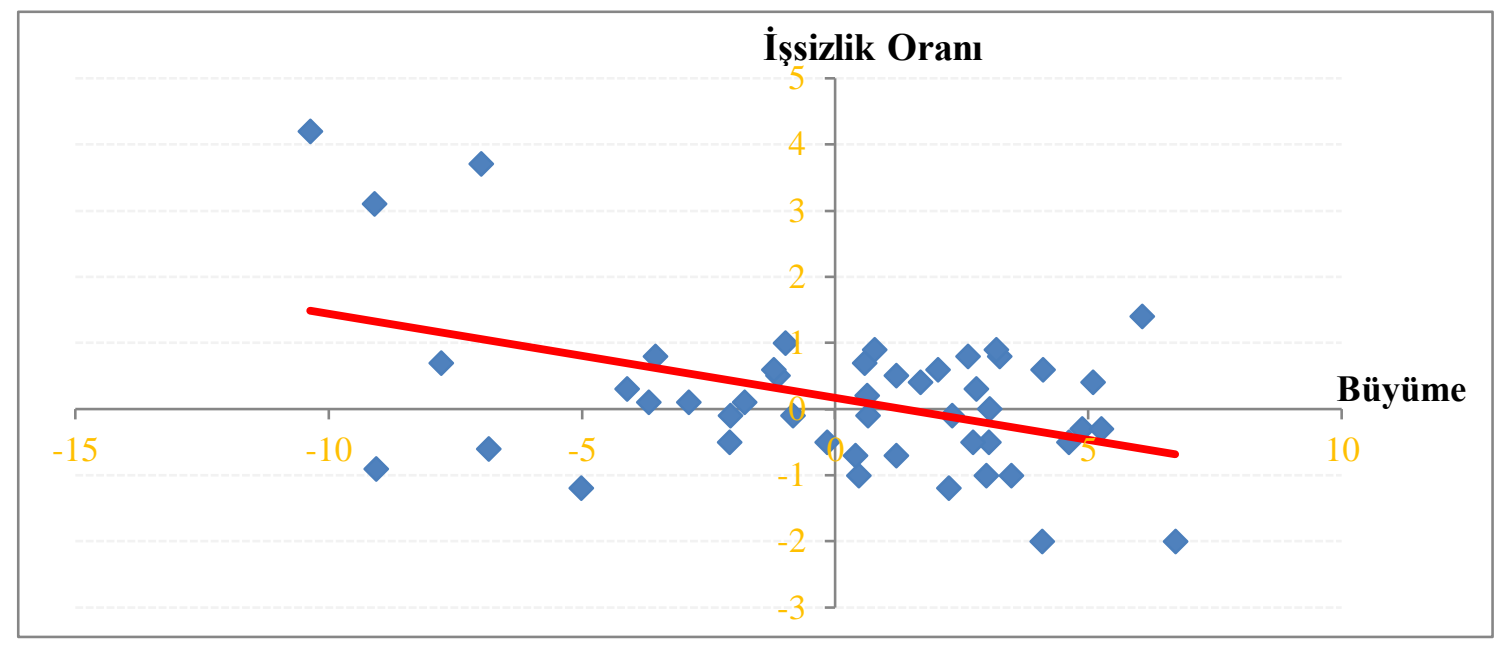

Grafik 5: Türkiye'de Ekonomik Büyüme ve İşsizlik Oranları Arasındaki ilişki (1972-2019) Kaynak: TÜiK (2014), World Bank (2019), Sabah (2019), Güney (2009), Yanbaşlı (2014) ve TUiK (2019). 2019 yllı verileri ilk 3 aylık dönemi kapsamaktadır.

Grafik 5'te 1972-2019 döneminde de işsizlik oranı ile ekonomik büyüme arasında zıt yönlü bir ilişki vardır. Ancak noktalar daha çok bir daire şeklinde dağılmıştır. Bu nedenle ilgili dönemde Türkiye ekonomisinde Okun Yasasının geçerliliğinin detaylı biçimde incelenmesi gerekmektedir. Türkiye ekonomisinde 1923-2019 döneminde işsizlik oranı ile ekonomik büyüme arasındaki ilişkilerin nokta dağılım grafiği ve buradan üretilen eğim çizgisi Grafik 6'da yer almaktadir.

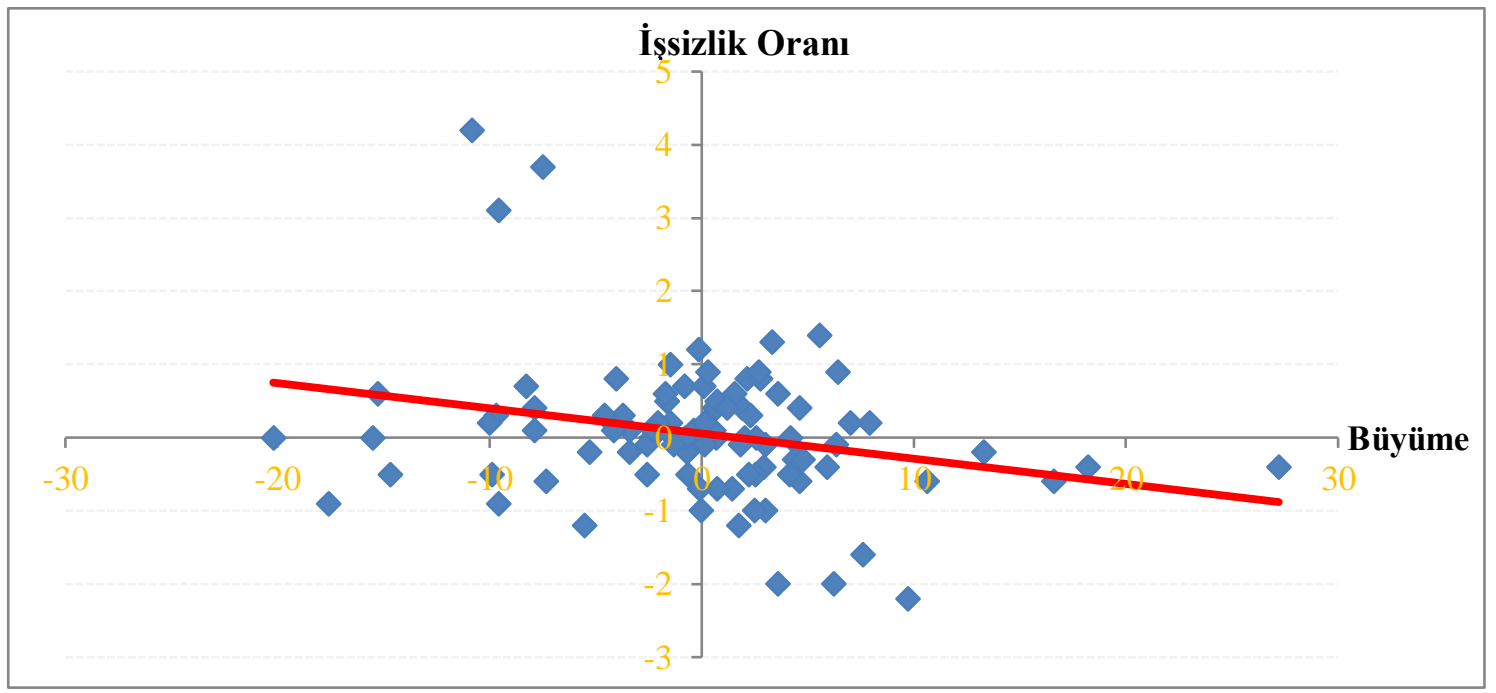

Grafik 6: Ekonomik Büyüme ve İşsizlik Oranları Arasındaki ilişki (1923-2019)

Kaynak: TÜİK (2014), World Bank (2019), Sabah (2019), Güney (2009), Yanbaşl1 (2014) ve TÜİK (2019). 2019 yıl1 verileri ilk 3 aylık dönemi kapsamaktadır. 
Grafik 6'dan da görüldüğü üzere; 1923-2019 döneminde işsizlik oranı ile ekonomik büyüme arasında zıt yönlü bir ilişki vardır. Ancak noktalar daha çok bir daire şeklinde dağılmıştır. Bu nedenle bu dönemde de Türkiye ekonomisinde Okun Yasasının geçerliliğinin detaylı biçimde incelenmesi gerekmektedir.

\section{LITERATÜR TARAMASI}

Literatürde Okun Yasasının geçerliliğini test etmeye yönelik çok sayıda çalışma bulunmakta olup, bunlar arasından seçilenlerin özeti, iki alt başlık altında okun yasasının geçerli olduğu ve okun yasasının geçerli olmadığı çalışmalar, yayınlanma tarihi sırasına göre verilmiştir.

\subsection{Okun Yasasının Geçerli Olduğunu Bulan Çalışmalar}

Shin, Yu ve Greenwood-Nimmo (2014), ABD, Kanada ve Japonya'da Okun Yasasının geçerliliğini, 1982:M02-2003:M11 dönemi verilerini kullanarak, ekonomik büyüme verisini pozitif ve negatif şoklara ayrıştırarak Nonlinear ARDL (NARDL) yöntemiyle test etmiş ve üç ülkede de pozitif ekonomik büyüme şoklarındaki artışların işsizliği azalttığını, negatif ekonomik büyüme şoklarının ise işsizliği artırdığını tespit etmiştir. Yani genel olarak bu ülkelerde Okun Yasası geçerlidir.

Stober (2015), İngiltere'de Okun Yasasının geçerliliğini, 1971-2013 dönemi verilerini kullanarak, ADF, PP birim kök testleri, Johansen eşbütünleşme testi ve EKK yöntemiyle analiz etmiş ve bu ülkede işsizlik oranını sabit tutabilmek için ekonomik büyümenin en az \%1,8 olması gerektiğini tespit etmiştir. Yazar gerçekleştirdiği regresyon analizinde, \%1,8'i aşan her 1 birimlik ekonomik büyümenin bu ülkedeki işsizlik oranını 0.07 puan azalttığı sonucuna da ulaşmıştır.

Alamro ve Al-dala'ien (2016) Ürdün'de Okun Yasasının geçerliliğini 1980-2011 dönemi verilerini kullanarak, ADF birim kök testi, Sınır Testi ve ARDL yöntemleriyle incelemiş ve bu ülkede ekonomik büyüme ile işsizlik arasında eşbütünleşme (uzun dönemli bir ilişki) olduğunu, milli gelirdeki \%1'lik artışının işsizliği \%0.013 puan azalttığını belirlemiştir. Modelin hata düzeltme mekanizmasının çalıştığının tespit edildiği çalışmada, ekonomik büyümenin işsizlik üzerindeki olumlu etkisinin kısa dönemde de geçerli olduğunu, ancak bu etkinin uzun dönemdekinden daha düşük ölçekte olduğunu tespit etmiştir.

Esmeraldo ve Veton (2019), Okun Yasasının Arnavutluk'ta geçerliliğini 1993-2000; 2001-2017 ve 1993-2017 dönemleri verilerini kullanarak, ülke geneli, kadınlar, erkekler ve gençler için ayrı ayrı incelemiş ve 1993-2000 ve 1993-2017 dönemlerinde hiçbir grupta Okun Yasasının geçerli olmadığını, sadece 2001-2017 döneminde gençlerde daha güçlü olmak üzere bu Yasanın geçerli oluğunu tespit etmiştir.

Stinespring ve Luciene (2019) Okun Yasasının ABD'nin Florida eyaletine bağlı kentlerde geçerliliğini 1990-2015 dönemi verilerini kullanarak analiz etmiş ve bu kentlerde ortalama (potansiyel) büyüme oranının \%1,7 - \%2,7 arasında olduğunu, bu oranların üzerine çıkan her 1 puanlık ekonomik büyümenin, bu illerdeki işsizlik oranlarını ortalama -0.19 puan ile -0.24 puan arasında azalttığını, bu yönüyle Florida eyaletinde Okun Yasasının geçerli olduğunu tespit etmiştir.

\subsection{Okun Yasasının Geçersiz Olduğunu Bulan Çalışmalar}

Máté (2010), OECD ülkelerinde Okun Yasasının geçerliliğini, 1962-2007 dönemi verilerini kullanarak analiz etmiş ve bu ülkelerde Okun Yasası ya da istihdam yaratmayan 
ekonomik büyüme teorileri yerine, düşük istihdam üreten ekonomik büyüme teorisinin geçerli olduğunu ifade etmiştir.

Muratoğlu (2011), Okun Yasasının Türkiye ekonomisinde geçerliliğini, 2000:Q12010:Q3 dönemi verilerini kullanarak, ADF, PP, KPSS, Zivot-Andrews birim kök testleri, EngleGranger ve Johansen eşbütünleşme testleri ve VAR analizi yöntemleriyle incelemiştir. Serilerin eşbütünleşik olmadığı, dolayısıyla Okun Yasasının geçerli olmadığı görülen çalışmada, etki-tepki fonksiyonlarının 6. dönemde dengeye geldiği, varyans ayrıştırmasında; işsizlikteki değişimlerin \%49.8'inin büyüme tarafından açıklanabildiğini, ancak ekonomik büyümedeki değişimlerin sadece \%6.4'ünün işsizlik tarafından açıklanabildiğini tespit etmiştir.

Léautier ve Hanson (2013), Afrika ülkelerinde 2008-2009 ve 2011-2012 dönemindeki ekonomik büyüme oranları ile işsizlik oranları arasındaki ilişkileri incelemiş ve bu ülkelerde ne fazla istihdam üreten sektörün tarım sektörü olduğunu, ayrıca pazar büyüklüğündeki ve yenilikçilik (inovasyon) seviyelerindeki artışların da bu ülkelerdeki işsizlik oranını azaltıcı etkilerinin olduğunu, ancak ekonomik büyüme ile işsizlik oranı arasında anlamlı bir ilişkinin söz konusu olmadığını tespit etmiştir.

Murat ve Yılmaz-Eser (2013), Türkiye'de istihdamsız ekonomik büyüme olgusunun geçerliliğini, 1970-2011 dönemi için incelemiş ve 1993, 2000, 2002, 2003 ve 2004 y1llarındaki büyümenin istihdamsız büyüme olduğunu tespit etmiştir.

Timur ve Doğan (2015), Türkiye'de istihdam yaratmayan ekonomik büyüme olgusunun geçerliliğini, 1980-2014 dönemi için ADF ve Granger testleriyle incelemiş ve ilgili dönemde Türkiye ekonomisinde ekonomik büyüme ile istihdam arasında herhangi bir nedensellik ilişkisinin olmadığını belirlemiştir.

Abdioğlu ve Albayrak (2016), Türkiye'de ekonomik büyüme trendinden sapma ile istihdam arasındaki ilişkileri, 1988-2015 dönemi için ADF ve EKK yöntemleriyle, alt sektörler itibariyle incelemiş ve sanayi, madencilik, imalat sanayi, hizmetler, inşaat ve ulaştırma sektörlerindeki büyümenin istihdam artışına imkân sağladığını, ancak genel ekonomide yaşanan büyümenin, istihdamı artırmadığını belirlemiştir.

Yüksel (2016), Rusya ekonomisinde Okun Yasasının geçerliliğini, 1992-2014 dönemi için ADF ve PP birim kök testleri, Engle-Granger eşbütünleşme testi, Granger ve Toda-Yamamoto nedensellik testleriyle araştırmıştır. Eşbütünleşme testi sonucunda işsizlik oranı ile ekonomik büyüme arasında uzun dönemli bir ilişki tespit edilmiştir. Granger nedensellik testi sonucunda; işsizlik oranından büyümeye doğru bir nedensellik tespit edilirken, ekonomik büyümeden işsizlik oranına doğru herhangi bir ilişki tespit edilememiştir. Toda-Yamamoto nedensellik testi sonucunda ise enflasyondan işsizliğe, işsizlikten ekonomik büyümeye doğru nedensellik ilişkileri belirlenirken, ekonomik büyümeden işsizliğe doğru bir etkileşim görülememiştir. Bu nedenle çalışmada; ilgili dönemde Rusya ekonomisinde Okun Yasasının geçerli olmadığına karar verilmiştir.

Yazıc1 (2018) Okun Yasasının geçerliliğini Türkiye'nin 1960-2015 dönemi verilerini kullanarak, ADF, PP birim kök testleri, Johansen ve Juselius (1990) eşbütünleşme testi ve VECM yöntemleriyle analiz etmiştir. İşsizlik ve ekonomik büyüme oranlarının I(1) oldukları belirlenen çalışmada, ancak \%10 anlamlılık düzeyinde bir eşbütünleşme ilişkisi tespit edilebilmiştir. FMOLS yöntemiyle gerçekleştirilen regresyon analizinde; işsizlik oranındaki artışın, ekonomik büyümeyi artırdığı görülmüş olup, bu sonuç Okun Yasası ile çelişmektedir. VECM nedensellik testinde ise işsizlik oranı ile ekonomik büyüme arasında herhangi bir nedensellik ilişkisi tespit edilememiştir.

Eğri (2018) Mısır ekonomisinde Okun Yasasının geçerliliğini, 1970-2016 dönemi için ADF, PP birim kök testleri, Johansen eşbütünleşme testi, EKK yöntemi ve Granger nedensellik testleri ile incelemiş ve bu dönemde ekonomik büyüme ile işsizlik arasında eşbütünleşmenin 
olmadığını, işsizlik oranı ile ekonomik büyük büyüme arasında herhangi bir nedensellik ilişkisinin olmadığını, kısaca bu dönemde Türkiye'de Okun Yasası'nın geçerli olmadığını tespit etmiştir.

Literatürde yer alan çalışmalara bakıldığında; Türkiye için 1923-2019 dönemini kapsayan, çoklu yapısal kırılmalı bir analiz olmadığı görülmüş olup, bu yönleriyle de çalışmanın literatüre bir katkı sağlaması beklenmektedir.

\section{EKONOMETRIKK ANALIZ}

\subsection{Veri Seti}

Bu çalışmada ekonomik büyüme ile işsizlik arasındaki ilişkiler 1923-20194 dönemi için analiz edilmiştir. Grafik 3'te 1972 yılından sonra işsizlik oranı ile ekonomik büyüme arasında bir ayrışma görüldüğü için ekonometrik analiz; 1923-2019; 1923-1971 ve 1972-2019 dönemleri için ayrı ayrı gerçekleştirilmiştir. Çalışmada bağımlı değişken olarak işsizlik oranındaki değişim $(\Delta u)$, bağımsız değişken olarak ise ekonomik büyümedeki trendden sapma $\left(g^{*}-g_{t}\right)$ verisi kullanılmıştır. Burada $g^{*}$; ilgili analiz dönemindeki ortalama ekonomik büyüme oranı olup, bu çalışmada tarafimızdan 1923-2019 dönemi için \%4,9, 1923-1971 dönemi için \%5,3, 1972-2019 dönemi için \%4,4 olarak hesaplanmıştır. Ekonomideki yapısal dönüşümlerin ${ }^{5}$ ve ekonomik krizlerin de analizlere kukla değişkenlerle eklenmesi düşünülmüş, ancak kriz dönemlerinde ekonomi küçülüp, işsizlik arttığı için Okun Yasası daha iyi gözlemlenebilmektedir. Kukla değişken kullanarak bu etkiler ortadan kaldırılmak istenmemiştir.

\subsection{Ekonometrik Model}

Bu çalışmada; Okun (1962) ve Stober (2015) izlenerek kullanılan ekonometrik model:

$$
\Delta u_{t}=\beta_{0}+\beta_{1}\left(g_{t}-g^{*}\right)+\varepsilon_{t}
$$

şeklindedir. Burada $\Delta u_{t} ; t$ döneminde işsizlik oranındaki değişimi, $g^{*}$; ilgili dönemdeki potansiyel (ortalama) ekonomik büyüme oranını, $g_{t} ; t$ dönemindeki ekonomik büyüme oranını, $g_{t}-g^{*}$; potansiyelin üzerindeki (veya altındaki) büyüme oranını, $\varepsilon_{t}$; ekonometrik olarak sorunsuz hata terimleri serisini ifade etmektedir. Bu modelin tahmini sonucunda; $\beta_{1}<0$ ve istatistiksel olarak anlamlı çıktığında; Okun Yasasının, $\beta_{1}>0$ ve istatistiksel olarak anlamlı çıktığında ise; İstihdam Yaratmayan Ekonomik Büyüme Teorisinin geçerli olduğuna karar verilecektir.

\subsection{Yöntem}

$\mathrm{Bu}$ çalışmada serilerin durağanlığı; Carrion-i-Silvestre vd. (2009) çoklu yapısal kırılmalı birim kök testi ile incelenmiştir. Seriler arasındaki eşbütünleşme ilişkileri; Maki (2012) çoklu yapısal kırılmalı eşbütünleşme testi ile analiz edilmiştir. Denklem (2)'de yer alan katsayılar DOLS (Dynamic Ordinary Least Squares: Dinamik En Küçük Kareler), FMOLS (Fully Modified Ordinary Least Squares: Tam Değiştirilmiş En Küçük Kareler) ve CCR (Canonical Cointegrating Regression: Kanonik Eşbütünleşik Regresyon) yöntemi ile elde edilmiştir. Değişkenler arasındaki nedensellik ilişkileri ise VECM'ye dayalı nedensellik testi yöntemiyle analiz edilmiştir.

\footnotetext{
${ }^{4} 2019$ verileri ilk 3 aylık dönemi kapsamaktadır.

524 Ocak 1980 kararları ve Gümrük Birliğine girilmesi gibi.
} 


\subsection{Uygulama}

\subsubsection{Birim Kök Testi}

Ekonometrik analizlerin sonuçlarının güvenilir olabilmesi için öncelikle serilerin durağanlık seviyelerinin belirlenmesi, sonraki analiz yöntemlerinin de bu sonuçlara göre belirlenmesi gerekmektedir. Bu çalışmada analiz dönemleri uzun olduğu ve analiz dönemlerinde ekonomiyi yakından etkileyen çok sayıda olay bulunduğu için serilerin durağanlıkları Carrion-iSilvestre vd. (2009) çoklu yapısal kırılmalı birim kök testiyle analiz edilmiştir. Bu yöntem, serideki 5 taneye kadar yapısal kırılma tarihinin varlı̆̆ını göz önünde bulundurarak birim kök sinaması yapabilmekte ve yapısal kırılma tarihlerini de kendisi belirleyebilmektedir. Carrion-iSilvestre vd. (2009) bu yöntemde birim kökün varlığını inceleyebilmek için 5 farklı test istatistiği geliştirmiştir:

$$
\begin{aligned}
& P_{T}\left(\lambda^{0}\right)=\left\{S\left(\bar{\alpha}, \lambda^{0}\right)-\bar{\alpha} S\left(1, \lambda^{0}\right)\right\} / s^{2}\left(\lambda^{0}\right) \\
& M P_{T}\left(\lambda^{0}\right)=\left[c^{-2} T^{-2} \sum_{t=-}^{T} y_{t-1}^{2}+(1-\bar{c}) T^{-1} y_{T}^{2}\right] / s\left(\lambda^{0}\right)^{2} \\
& M Z_{\alpha}\left(\lambda^{0}\right)=\left(T^{-1} y_{T}^{2}-s\left(\lambda^{0}\right)^{2}\right)\left(2 T^{-2} \sum_{t=-}^{T} y_{t-1}^{2}\right)^{-1} \\
& M S B\left(\lambda^{0}\right)=\left(s\left(\lambda^{0}\right)^{-2} T^{-2} \sum_{t=-}^{T} y_{t-1}^{2}\right)^{-1 / 2} \\
& M Z_{t}\left(\lambda^{0}\right)=\left(T^{-1} y_{T}^{2}-s\left(\lambda^{0}\right)^{2}\right)\left(4 s\left(\lambda^{0}\right) T^{-2} \sum_{t=-}^{T} y_{t-1}^{2}\right)^{-1 / 2}
\end{aligned}
$$

Buradan $M Z_{\alpha}$ ve $M Z_{t}$ testlerinin hipotezleri;

$H_{0}$ : Seri durağan değildir.

$H_{1}$ : Seri durağandır.

$P_{T}, M S B$ ve $M P_{T}$ testlerinin hipotezleri;

$H_{0}$ : Seri durağandır.

$H_{1}$ : Seri durağan değildir.

biçimindedir. Bu hipotezleri test edebilmek için gereken kritik değerler, Carrion-i-Silvestre vd. (2009) tarafindan yazılan Gauss kodunda bootstrap döngüsü kurularak üretilebilmektedir. Bu çalışmada Carrion-i-Silvestre vd. (2009) çoklu yapısal kırılmalı birim kök testi, Gauss 10 programı ve Carrion-i-Silvestre vd. (2009) tarafindan bu programlama dilinde yazılmış kod kullanılarak yapılmış ve elde edilen bulgular Tablo 1'de rapor edilmiştir. 
Optimum Journal of Economics and Management Sciences, Vo1.7, No. 1- http://dergipark.gov.tr/optimum Uslu-Jobless Economic Growth: An Econometric Analysis for Turkey in the Framework of Okun Law

Tablo 1: Carrion-i-Silvestre vd. (2009) Çoklu Yapısal Kırılmalı Birim Kök Testi Sonuçları

\begin{tabular}{|c|c|c|c|c|c|c|c|}
\hline $\begin{array}{l}\text { Analiz } \\
\text { Dönemi }\end{array}$ & Değişken & $\boldsymbol{P}_{T}$ & $\boldsymbol{M P}_{T}$ & $M Z_{\alpha}$ & $M S B$ & $M Z_{t}$ & $\begin{array}{c}\text { Yapisal Kirtlma } \\
\text { Tarihleri }\end{array}$ \\
\hline \multirow{4}{*}{ 1923-1971 } & $\boldsymbol{u}$ & $\begin{array}{l}18.67 \\
(8.93)\end{array}$ & $\begin{array}{l}18.04 \\
(8.93)\end{array}$ & $\begin{array}{c}-23.09 \\
(-45.90)\end{array}$ & $\begin{array}{c}0.14 \\
(0.10)\end{array}$ & $\begin{array}{l}-3.39 \\
(-4.78)\end{array}$ & $\begin{array}{c}1929 ; 1934 ; 1942 ; \\
1950 ; 1966\end{array}$ \\
\hline & $g$ & $\begin{array}{l}18.06 \\
(8.50)\end{array}$ & $\begin{array}{l}16.70 \\
(8.50)\end{array}$ & $\begin{array}{c}-23.19 \\
(-45.42)\end{array}$ & $\begin{array}{l}0.14 \\
(0.10)\end{array}$ & $\begin{array}{l}-3.40 \\
(-4.75)\end{array}$ & $\begin{array}{c}1928 ; 1934 ; 1939 ; \\
1945 ; 1953\end{array}$ \\
\hline & $\Delta u$ & $\begin{array}{r}4.27 * * \\
(5.54)\end{array}$ & $\begin{array}{l}4.30 * * \\
(5.54)\end{array}$ & $\begin{array}{l}-21.16^{* *} \\
(-17.32)\end{array}$ & $\begin{array}{l}0.15^{* *} \\
(0.16)\end{array}$ & $\begin{array}{l}-3.25 * * \\
(-2.89)\end{array}$ & 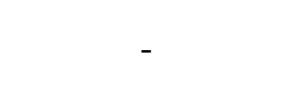 \\
\hline & $\Delta g$ & $\begin{array}{c}1.49 \\
(1.21)\end{array}$ & $\begin{array}{c}1.55 \\
(1.21)\end{array}$ & $\begin{array}{r}-15.89 * * \\
(-14.83)\end{array}$ & $\begin{array}{l}0.17 * * \\
(0.21)\end{array}$ & $\begin{array}{l}-2.81 * * \\
(-2.33)\end{array}$ & - \\
\hline \multirow{4}{*}{ 1972-2019 } & $\boldsymbol{u}$ & $\begin{array}{l}18.60 \\
(7.03)\end{array}$ & $\begin{array}{l}16.14 \\
(7.03)\end{array}$ & $\begin{array}{l}-19.19 \\
(-42.51)\end{array}$ & $\begin{array}{l}0.15 \\
(0.10)\end{array}$ & $\begin{array}{l}-3.06 \\
(-4.63)\end{array}$ & $\begin{array}{c}\text { 1985; 1995; 2000; } \\
\text { 2009; } 2014\end{array}$ \\
\hline & $\boldsymbol{g}$ & $\begin{array}{l}19.35 \\
(9.39)\end{array}$ & $\begin{array}{l}19.35 \\
(9.39)\end{array}$ & $\begin{array}{c}-23.34 \\
(-46.90)\end{array}$ & $\begin{array}{c}0.14 \\
(0.10)\end{array}$ & $\begin{array}{l}-3.35 \\
(-4.80)\end{array}$ & $\begin{array}{c}\text { 1976; 1987; 1993; } \\
\text { 1998; } 2003\end{array}$ \\
\hline & $\Delta u$ & $\begin{array}{l}5.25 * * \\
(5.54)\end{array}$ & $\begin{array}{l}5.26 * * \\
(5.54)\end{array}$ & $\begin{array}{l}-20.32 * * \\
(-17.32)\end{array}$ & $\begin{array}{l}0.15^{* *} \\
(0.16)\end{array}$ & $\begin{array}{l}-3.05 * * \\
(-2.89)\end{array}$ & - \\
\hline & $\Delta g$ & $\begin{array}{l}5.05 * * \\
(0.54)\end{array}$ & $\begin{array}{l}5.08 * * \\
(5.54)\end{array}$ & $\begin{array}{r}-18.48 * * \\
(-17.32)\end{array}$ & $\begin{array}{c}0.163 * * \\
(0.168)\end{array}$ & $\begin{array}{l}-3.01 * * \\
(-2.89)\end{array}$ & - \\
\hline \multirow{4}{*}{ 1923-2019 } & $\boldsymbol{u}$ & $\begin{array}{l}7.69 \\
(6.85)\end{array}$ & $\begin{array}{c}7.30 \\
(6.85)\end{array}$ & $\begin{array}{l}-42.19 \\
(-42.95)\end{array}$ & $\begin{array}{c}0.108 \\
(0.107)\end{array}$ & $\begin{array}{l}-4.57 \\
(-4.66)\end{array}$ & $\begin{array}{c}\text { 1934; 1966; 1981; } \\
\text { 1996; 2009 }\end{array}$ \\
\hline & $\boldsymbol{g}$ & $\begin{array}{c}8.92 \\
(6.75)\end{array}$ & $\begin{array}{c}8.79 \\
(6.75)\end{array}$ & $\begin{array}{l}-36.58 \\
(-43.31)\end{array}$ & $\begin{array}{c}0.11 \\
(0.10)\end{array}$ & $\begin{array}{l}-4.21 \\
(-4.69)\end{array}$ & $\begin{array}{c}\text { 1935; 1949; 1976; } \\
\text { 1993; } 2006\end{array}$ \\
\hline & $\Delta u$ & $\begin{array}{c}2.88 * * \\
(5.54)\end{array}$ & $\begin{array}{r}2.86 * * \\
(5.54)\end{array}$ & $\begin{array}{c}-44.03 * * \\
(-17.32)\end{array}$ & $\begin{array}{l}0.10^{* *} \\
(0.16)\end{array}$ & $\begin{array}{l}-4.53 * * \\
(-2.89)\end{array}$ & - \\
\hline & $\Delta g$ & $\begin{array}{c}2.71 * * \\
(5.54)\end{array}$ & $\begin{array}{l}2.76 * * \\
(5.54)\end{array}$ & $\begin{array}{c}-33.36 * * \\
(-17.32)\end{array}$ & $\begin{array}{l}0.12 * * \\
(0.16)\end{array}$ & $\begin{array}{c}-4.07 * * \\
(-2.89)\end{array}$ & - \\
\hline
\end{tabular}

Not: **; İlgili serinin $\% 5$ anlamlılık düzeyinde durağan olduğunu göstermektedir. Parantez içindekiler, 1000 yinelemeli bootstrap döngüsü ile ilde edilmiş, $\% 5$ anlamlılık düzeyindeki kritik değerlerdir. Sadece serilerin düzey değerlerinde yapılan testte yapısal kırılmaya izin verilerek, gerçek yapısal kırılma tarihleri belirlenmeye çalışılmıştır.

Tablo 1'deki sonuçlara göre serilerin hepsi düzey değerlerinde değil, birinci farklarında durağan olmuş̧tur. Bu durumda bütün seriler I(1)'dir. Bu serilerin düzey değerleriyle yapılacak regresyon analizlerinde sapmalı sonuçlara ulaşılabilecektir. Bu sebeple öncelikle seriler arasında eşbütünleşme ilişkisinin varlığının test edilmesi gerekmektedir. Carrion-i-Silvestre vd. (2009) testinin, Türkiye ekonomisindeki önemli yapısal kırılma tarihlerini de başarılı bir şekilde belirlediği görülmektedir. Bu tarihlerden 1929; Büyük Buhranın başladığı, 1934; bittiği, 1939; II. Dünya Savaşının başladığı, 1945; bittiği, 1950; çok partili sisteme geçilen, 1981; dişa dönük ekonomik büyüme modelinin uygulanmaya başladığı yılları, 1993, 2000 ve 2009; sırasılyla 1994, 2001 ve 2008 ekonomik krizlerini göstermektedir.

\subsubsection{Eşbütünleşme Testi}

Bu çalışmada analiz dönemi uzun olduğu ve bu dönemlerde ekonomiyi yakından etkileyen çok sayıda yapısal dönüşüm ve ekonomik krizler bulunduğu için seriler arasındaki eşbütünleşme ilişkileri Maki (2012) çoklu yapısal kırılmalı eşbütünleşme testiyle incelenmiştir. Bu testte; eşbütünleşme vektöründeki 5 taneye kadar yapısal kırılma göz önünde bulundurulabilmekte, yapısal kırılma sayısı ve yapısal kırılma tarihleri test yöntemi tarafindan otomatik olarak belirlenebilmektedir. Maki (2012) bu testinde 4 farklı model oluşturmuştur: 
Model 0: Sabitte kırılmalı trendsiz model:

$$
y_{t}=\mu+\sum_{j=1}^{m} \mu_{j} K_{j t}+\beta x_{t}+\varepsilon_{t}
$$

Model 1: Sabit terimde ve eğimde kırılmalı trendsiz model:

$$
y_{t}=\mu+\sum_{j=1}^{m} \mu_{j} K_{j t}+\beta x_{t}+\sum_{j=1}^{m} \beta_{j} x_{j} K_{j t}+\varepsilon_{t}
$$

Model 2: Sabit terimde ve eğimde kırılmalı trendli model:

$$
y_{t}=\mu+\sum_{j=1}^{m} \mu_{j} K_{j t}+\gamma x+\beta x_{t}+\sum_{j=1}^{m} \beta_{j} x_{j} K_{j t}+\varepsilon_{t}
$$

Model 3: Sabit terimde, eğimde ve trendde kırılmalı model:

$$
y_{t}=\mu+\sum_{j=1}^{m} \mu_{j} K_{j t}+\gamma t+\sum_{j=1}^{m} \gamma_{j} t K_{j t}+\beta x_{t}+\sum_{j=1}^{m} \beta_{j} x_{j} K_{j t}+\varepsilon_{t}
$$

$\mathrm{Bu}$ testin hipotezleri;

$$
H_{0} \text { : Yapısal kırılmalar varken seriler eşbütünleşik değildir }
$$

$H_{1}$ : Yapısal kırılmalar varken seriler eşbütünleşiktir

biçimindedir. Bu hipotezleri sınayabilmek için ihtiyaç duyulan kritik değerler Maki (2012: 3)'te

\begin{tabular}{|c|c|c|c|c|c|c|}
\hline \multirow{2}{*}{ Dönem } & \multirow{2}{*}{ Model } & \multirow{2}{*}{ Test Istatistiği } & \multicolumn{3}{|c|}{ Kritik Değerler } & \multirow{2}{*}{$\begin{array}{c}\text { Yapisal Kırılma } \\
\text { Tarihleri }\end{array}$} \\
\hline & & & $\% 1$ & $\% 5$ & $\% 10$ & \\
\hline \multirow{4}{*}{ 1923-1971 } & Model 0 & $-5.25^{*}$ & -5.95 & -5.42 & -5.13 & $1931 ; 1958$ \\
\hline & Model 1 & -4.74 & -6.19 & -5.69 & -5.44 & $1943 ; 1957$ \\
\hline & Model 2 & -4.46 & -6.91 & -6.35 & -6.05 & 1934; 1954; 1962 \\
\hline & Model 3 & -5.38 & -8.00 & -7.41 & -7.11 & 1941 \\
\hline \multirow{4}{*}{$1972-2019$} & Model 0 & $-6.47 * * *$ & -5.95 & -5.42 & -5.13 & $1998 ; 2013$ \\
\hline & Model 1 & $-6.51 * * *$ & -6.19 & -5.69 & -5.44 & $1980 ; 1986$ \\
\hline & Model 2 & $-8.03 * * *$ & -6.91 & -6.35 & -6.05 & 1994; 1999 \\
\hline & Model 3 & $-8.002 * * *$ & -8.00 & -7.41 & -7.11 & 1989; 2004 \\
\hline \multirow{4}{*}{ 1923-2019 } & Model 0 & -4.49 & -5.95 & -5.42 & -5.13 & 1952; 1978; 2000 \\
\hline & Model 1 & $-5.45^{*}$ & -6.19 & -5.69 & -5.44 & 1929; 1944; 1972; 1977 \\
\hline & Model 2 & $-10.48 * * *$ & -6.91 & -6.35 & -6.05 & $\begin{array}{c}1930 ; 1952 ; 1994 ; 1999 ; \\
2009\end{array}$ \\
\hline & Model 3 & $-10.06^{* * * *}$ & -8.00 & -7.41 & -7.11 & 1977; 1994; 1999 \\
\hline
\end{tabular}
verilmiştir. Bu çalışmada Maki (2012) çoklu yapısal kırılmalı eşbütünleşme testi, Gauss 10 programı ve Maki (2012) tarafından bu programlama dilinde yazılmış kod kullanılarak yapılmış ve elde edilen bulgular Tablo 2'de rapor edilmiştir.

Tablo 2: Maki (2012) Çoklu Yapısal Kırılmalı Eşbütünleşme Testine Ait Bulgular

Not: *** ve *; ilgili modelde sırasıyla \%1 ve \%10 anlamlılık düzeylerinde eşbütünleşme ilişkisinin bulunduğunu ifade etmektedir.

Tablo 2'deki bulgulara göre; bütün dönemler için en az bir modelde işsizlik oranı ile ekonomik büyüme oranı arasında eşbütünleşme ilişkisi vardır. Bu nedenle, bu serilerle yapılacak regresyon analizlerinde, sahte regresyon sorunu ile karşılaşılmayacaktır. Maki (2012) çoklu yapısal kırılmalı eşbütünleşme testinin de Türkiye ekonomisindeki önemli yapısal kırılma tarihlerini başarılı bir şekilde belirlediği görülmektedir. Bu tarihlerden 1929-1994; Büyük Buhran yıllarını, 1939-1944; II. Dünya Savaşı yıllarını, 1950-1960; liberal ekonomi politikalarının 
uygulandığı dönemi, 1980; dişa dönük ekonomik büyüme modelinin uygulanmaya başladığı yılları, 1994, 2000 ve 2009; ilgili dönemlerdeki ekonomik krizleri göstermektedir.

\subsubsection{Regresyon Analizi}

Regresyon analizi kapsamında Denklem (2), her bir dönem için ayrı ayrı tahmin edilmiştir. $\mathrm{Bu}$ tahmin işleminde; DOLS, FMOLS ve CCR yöntemleri bir arada kullanılmıştır. Bu yöntemlerden DOLS; serilerin gecikmeli ve öncül değerlerini de modele açıklayıcı değişken olarak ilave ederek, otokorelasyon ve değişen varyans sorunlarına karşı dirençli tahminler elde etmektedir. (Gujarati ve Porter, 2012). FMOLS; gözlem sayısı düşük olduğunda otokorelasyon ve değişen varyans sorunlarına karşı dirençli tahminler elde etmektedir. CCR yöntemi ise; OLS yönteminden kaynaklanan sapmaları ortadan kaldırmada etkin bir tahmin yöntemidir (Nazlıoğlu, 2010: 99). Yapılan regresyon analizine ait bulgular Tablo 3'te rapor edilmiştir

Tablo 3: Regresyon Analizi Sonuçları

\begin{tabular}{cccccccccc}
\hline & \multicolumn{3}{c}{ 1923-1971 Dönemi } & \multicolumn{3}{c}{ 1972-2019 Dönemi } & \multicolumn{3}{c}{ 1923-2019 Dönemi } \\
& DOLS & FMOLS & CCR & DOLS & FMOLS & CCR & DOLS & FMOLS & CCR \\
\hline $\boldsymbol{\beta}_{\mathbf{0}}$ & $-4.74^{* * *}$ & -0.007 & -0.008 & $-3.90^{* * *}$ & 0.16 & 0.16 & $-0.37^{* * *}$ & 0.07 & 0.07 \\
& $(0.00)$ & $(0.93)$ & $(0.92)$ & $(0.00)$ & $(0.27)$ & $(0.28)$ & $(0.00)$ & $(0.42)$ & $(0.42)$ \\
$\boldsymbol{\beta}_{\mathbf{1}}$ & $-0.33^{* *}$ & $-0.01^{*}$ & -0.023 & $0.63^{*}$ & $0.12^{* * *}$ & $0.11^{* *}$ & $-0.03^{*}$ & $-0.03^{* * *}$ & $-0.04^{* *}$ \\
$\boldsymbol{R}^{2}$ & $0.03)$ & $(0.09)$ & $(0.15)$ & $(0.07)$ & $(0.00)$ & $(0.01)$ & $(0.06)$ & $(0.00)$ & $(0.02)$ \\
$\overline{\boldsymbol{R}}^{2}$ & 0.58 & 0.001 & -0.03 & 0.84 & 0.19 & 0.19 & 0.85 & 0.05 & 0.04 \\
$\boldsymbol{S E R}$ & 0.36 & 0.020 & -0.05 & 0.54 & 0.16 & 0.18 & 0.33 & 0.04 & 0.03 \\
$\boldsymbol{S S R}$ & 0.78 & 12.43 & 0.53 & 0.83 & 1.08 & 1.08 & 0.83 & 0.90 & 0.90 \\
\hline
\end{tabular}

Not: ***,** ve *; İlgili katsayının sırasıyla $\% 1, \% 5$ ve $\% 10$ düzeyinde istatistiksel olarak anlamlı olduğunu göstermektedir. Parantez içindekiler, olasılık değerleridir. SER: Standart Error of Regression (Tahminin standart hatası) ve SSR; Sum Squared of Resid (Hata terimlerinin kareleri toplamı) olup, bu değerlerin küçük olması, yapılan tahminin başarılı olduğunu göstermektedir.

Tablo 3'te DOLS yöntemiyle yapılan tahmin sonuçlarında belirlilik katsayılarının $\left(R^{2}\right.$ ve $\bar{R}^{2}$ ) daha büyük, model standart hatalarının (SER) ve hata terimlerinin kareleri toplamının (SSR) daha küçük olduğu görülmektedir. Bu nedenle DOLS yöntemiyle elde edilen sonuçlar temel alınmıştır. Buna göre; Türkiye ekonomisinde 1923-1971 döneminde Okun Yasası geçerlidir. Bu dönemde $\% 5,3$ olan ortalama büyüme oranının üzerindeki her $\% 1$ puanlık ekonomik büyüme, işsizlik oranında \%0.33 puan düşüşe neden olmuştur. 1972-2019 döneminde ise \%4,4 olan ortalama ekonomik büyüme oranının üzerindeki her \%1 puanlık ekonomik büyüme, işsizliği $\% 0.63$ puan artırmıştır. Bu nedenle Türkiye ekonomisinde 1972-2019 döneminde İstihdam Yaratmayan Ekonomik Büyüme Teorisi geçerli olmuştur. Yani bu dönemde ekonomik büyüme artmasına rağmen, işsizlikte azalma olmamış, hatta düşük bir anlamlılık düzeyinde olsa da işsizlikte artma yaşanmıştır. Bu durumun nedenlerinin, Kigabo ve Kamanzi (2018: 12) çalışmasıyla uyumlu biçimde, ilgili dönemde Türkiye ekonomisinde yaşanan hızlı nüfus artış1, verimlilik artışı ve kapasite kullanım oranındaki yükselişler olduğu değerlendirilmektedir. Elde edilen bu sonuç, literatürde yer alan Murat ve Yılmaz-Eser (2013) çalışmasının bulgularıyla tutarlıdır. Genel olarak 1923-2019 döneminde ise Okun Yasası düşük bir anlamlılık düzeyinde olsa da geçerlidir. Bu dönemde \%4,9 olan ortalama büyüme oranının üzerindeki her \%1 puanlık ekonomik büyüme, işsizlik oranında $\% 0.03$ puan düşüşe olanak sağlamıştır. Bu bölümde elde edilen bulgular genel olarak literatürde yer alan Esmeraldo ve Veton (2019) çalışmasıyla benzerlik göstermektedir. $\mathrm{Bu}$ tahminlerde otokorelasyon sorunun olmadığı ve atıkların normal dağılıma sahip olduğuyla ilgili grafikler, Ek 1 - Ek 3’te yer almaktadır. 


\subsubsection{Nedensellik Testi}

$\mathrm{Bu}$ çalışmada, seriler arasında eşbütünleşme ilişkisi tespit edildiği için işsizlik oranındaki değişme $(u)$ ile ekonomik büyümede trendden sapma $(g)$ arasında nedensellik ilişkilerinin varlığı Vektör Hata Düzeltme Modelin (Vector Error Correction Model: VECM) dayalı olarak analiz edilmiştir. Bu yöntemde; nedensellik ilişkisi kısa ve uzun dönem nedensellik ilişkileri olarak ayrıştııılmaktadır. $\mathrm{Bu}$ yöntemde nedensellik ilişkileri aşağıdaki eş-anlı denklem sistemi yardımıyla gerçekleştirilmiştir (Shahbaz ve Dube, 2012: 180-181):

$$
\begin{aligned}
& \Delta u_{t}=\alpha_{0}+\sum_{j=1}^{m} \alpha_{j} \Delta u_{t-j}+\sum_{j=1}^{m} \beta_{j} \Delta g_{t-j}+\gamma E C T_{1, t-1}+\omega_{t} \\
& \Delta g_{t}=\psi_{0}+\sum_{j=1}^{m} \xi_{j} \Delta g_{t-j}+\sum_{j=1}^{m} \Theta_{j} \Delta u_{t-j}+\delta E C T_{2, t-1}+\eta_{t}
\end{aligned}
$$

Burada $m$; optimum gecikme uzunluğudur. Denklem (12) için sınanacak hipotezler;

$H_{01}: \beta_{j}=0 \quad g^{\prime}$ den $u^{\prime}$ ya doğru bir nedensellik ilişkisi yoktur.

$H_{A 1}: \beta_{j} \neq 0 \quad g^{\prime}$ den $u$ 'ya doğru bir nedensellik ilişkisi vardır.

şeklindedir. Denklem (13) için sınanacak hipotezler;

$H_{02}: \Theta_{j}=0 \quad u$ 'dan $g$ 'ye doğru bir nedensellik ilişkisi yoktur.

$H_{A 2}: \Theta_{j} \neq 0 \quad u^{\prime}$ dan $g^{\prime}$ ye doğru bir nedensellik ilişkisi vardır.

şeklindedir. Burada $H_{01}$ reddedilebilirse; $g^{\prime}$ den $u$ ya doğru, $H_{02}$ reddedilebilirse; $u^{\prime}$ dan $g$ 'ye doğru, her ikisi de reddedilebilirse karşılıklı nedensellik ilişkilerinin olduğuna, her iki hipotez de kabul edilecek olursa; bu değişkenler arasında herhangi bir nedensellik ilişkisinin olmadığına karar verilecektir.

VECM'ye dayalı nedensellik testini yapabilmek için öncelikle optimum gecikme uzunluklarının belirlenmesi gerekmektedir. Bunun için standart VAR tahminleri yapılmış ve elde edilen sonuçlar Ek 4 - Ek 6'da sunulmuştur. Bu gecikme uzunlukları kullanılarak gerçekleştirilen VECM'ye dayalı nedensellik testine ait bulgular Tablo 4'te yer almaktadır.

Tablo 4: VECM'ye Dayalı Nedensellik Testi Sonuçları

\begin{tabular}{ccccc}
\hline \multirow{2}{*}{ Dönem } & Etkilenen & \multicolumn{2}{c}{ Kısa Dönem Nedensellik } & Uzun Dönem Nedensellik \\
& Etkileyen & $\Delta \boldsymbol{u}$ & $\Delta \boldsymbol{g}$ & $\boldsymbol{E C T}_{\boldsymbol{t}-\mathbf{1}}$ \\
\hline \multirow{2}{*}{$\mathbf{1 9 2 3 - 1 9 7 1}$} & $\Delta \boldsymbol{u}$ & - & 7.40 & $-0.26^{* *}$ \\
& $\Delta \boldsymbol{g}$ & 0.84 & $(0.11)$ & $(0.01)$ \\
& $\Delta \boldsymbol{u}$ & $(0.93)$ & - & $-1.33^{* *}$ \\
$\mathbf{1 9 7 2 - 2 0 1 8}$ & $\Delta \boldsymbol{g}$ & - & 1.35 & $(0.01)$ \\
& $\Delta \boldsymbol{u}$ & $(0.60)$ & - & $-0.71)$ \\
& & - & 4.58 & $(0.00)$ \\
\hline $\mathbf{1 9 2 3 - 2 0 1 8}$ & $\Delta \boldsymbol{g}$ & 5.33 & $(0.33)$ & \\
\hline
\end{tabular}

Not: ** ve ${ }^{* * *}$; sırasıyla $\% 5$ ve $\% 1$ anlamlllık düzeyinde nedensellik ilişkisinin bulunduğunu ifade etmektedir.

Tablo 4'teki sonuçlara göre; Türkiye ekonomisinde işsizlik oranı ile ekonomik büyüme arasında kısa dönemde herhangi bir nedensellik ilişş̧i tespit edilemezken, uzun dönemli 
nedensellik ilişkileri vardır. Bu sonuç, iktisat teorisine de uygundur. Çünkü ekonomik büyüme ve işsizliğin birbirini kısa dönemden ziyade, uzun dönemde etkilemesi beklenmektedir. Elde edilen bu sonuç, literatürde yer alan Timur ve Doğan (2015) çalışmasının bulgularıyla uyum içindedir.

\section{SONUÇ VE DEĞERLENDİRME}

İşsizlik en önemli makroekonomik sorunlardan biri olup, ülkelerin öncelikli olarak eğilmeleri gereken bir konudur. Aksi takdirde kişi ve toplum hayatını yakından etkileyecek pek çok zararlı etkileri olabilmektedir. İşsizliğin nasıl azaltılabileceği konusunda ekonomistler uzun yıllardır çalışmalar yapmakta, teoriler geliştirmektedir. Okun Yasası da bu alanda ün kazanmış önemli bir teori olup, politika yapıcılara 1şık tutabilmektedir. Ancak geliştirilen teoriler, her ülke için ve her dönemde geçerli olmayabilmektedir. Bu nedenle, teorilerin ülkeler için geçerliliğinin siklıkla test edilmesinde ve politika önerilerinin buna göre geliştirilmesinde yarar vardır.

Bu çalışmada Okun Yasasının Türkiye ekonomisinde geçerliliği; 1923-2019 dönemi için analiz edilmiş, analiz ayrıca 1923-1971 ve 1972-2019 dönemleri için de yinelenmiştir. Analiz dönemi uzun olduğu ve analiz dönemlerinde Türkiye ekonomisini yakından etkileyen pek çok iç ve dış faktörler bulunduğu için serilerin durağanlığı Carrion-i-Silvestre vd. (2009) çoklu yapısal kırılmalı birim kök testi ile incelenmiş ve serilerin I(1) oldukları belirlenmiştir. Benzer gerekçelerle seriler arasındaki eşbütünleşme ilişkileri de Maki (2012) çoklu yapısal kırılmalı eşbütünleşme testi ile incelenmiş ve seriler arasında eşbütünleşme ilişkisinin olduğu bulunmuştur.

Regresyon katsayıları DOLS, FMOLS ve CCR yöntemleriyle tahmin edilmiş ve Okun Yasasının Türkiye ekonomisinde 1923-1971 döneminde güçlü, 1923-2019 döneminde zayıf formda geçerli olduğu, 1972-2019 döneminde ise İstihdam Yaratmayan Ekonomik Büyüme Teorisinin geçerli olduğu belirlenmiştir. Buna göre 1923-1971 döneminde \%5,3'ün üzerindeki her \%1 puanlık ekonomik büyüme, işsizlik oranını \%0.33 puan, 1923-2019 döneminde ise \%4,9'un üzerinde gerçekleşen her $\% 1$ puanlık ekonomik büyüme işsizlik oranını $\% 0.03$ puan azaltmıştır. 1972-2019 döneminde ise \%4,4'ün üzerindeki her \%1 puanlık ekonomik büyüme, işsizliği \%0.63 puan artırmıştır. 1972-2019 dönemi için elde edilen bu sonucun arkasında; 1980 sonrasında izlenen ihracat öncüllü ekonomik büyüme modeli, 1996 yılında Gümrük Birliğine girilmesiyle birlikte artan dış rekabet baskısı karşısında Ar\&Ge ve inovasyon çalışmalarına yönelinmesi sayesinde yaşanan verimlilik artışı, kapasite kullanım oranı artışı ve sermaye yoğun üretim stratejilerine geçişin ve kısmen de son yillarda Orta Doğu ve Asya ülkelerinden gelen göç olaylarının ve hızlı nüfus artışının olduğu değerlendirilmektedir.

Yapılan VECM nedensellik testi sonuçlarına göre; Türkiye ekonomisinde işsizlik oranı ile ekonomik büyüme arasında kısa dönemde herhangi bir nedensellik ilişkisi tespit edilemezken, uzun dönemli nedensellik ilişkileri belirlenmiştir.

$\mathrm{Bu}$ çalışmadan elde edilen sonuçlara dayanarak; Türkiye'de işsizliği azaltabilmek için ekonomik büyüme haricinde argümanlara da ihtiyaç olduğu, ülkedeki nüfus artış hızı ve göç olaylarının fazla olması nedeniyle ekonomik büyüme kanalıyla üretilen istihdamın yetersiz kaldığ 1 söylenebilir. Bu noktada ileride işsizliğe bağlı sosyal patlamalar olmaması için ülkenin göç politikasının tekrar gözden geçirilmesinin gerektiği, işe alımlarda göçmenlerin değil, yurttaşların öncelikli olmasının icap ettiği unutulmamalıdır. İstihdamı artırabilmek için işverenlerin üzerindeki vergi ve pirim yüklerinin azaltılması, ülkeye daha fazla yabancı yatırım çekebilmek ve yerli firmaların yeni yatırımlar yapabilmeleri için ülkedeki siyasi ve ekonomik istikrarın sağlanması, hukukun üstünlüğü ve mülkiyet hakları noktasında evrensel hukuk normlarına uyulması vazgeçilmez önceliklerdir. İstihdam politikaları şeffaf, liyakata dayalı ve bütün toplumu kucaklayıcı nitelikte olmalıdır. Aksi takdirde ülkenin yetişmiş nitelikli işgücü başka ülkelere gidebilmekte ya da çalışma motivasyonunu ve verimliliğini kaybedebilmektedir. 


\section{KAYNAKÇA}

Abdioğlu, Z. ve Albayrak, N. (2017). İstihdam Yaratmayan Büyüme: Alt Sektörler Bazında Bir Araştırma. Karadeniz Teknik Üniversitesi, Sosyal Bilimler Enstitüsü Sosyal Bilimler Dergisi, 7(3), 2015-228.

Agerbo, E. (2003). Unemployment and Suicide. Journal of Epidemiology \& Community Health 57(8), 560-561.

Alamro, H. and Al-dala'ien, Q. (2016). Validity of Okun's Law: Empirical Evidence from Jordan. Dirasat, Administrative Sciences, 43(1), 315-324.

Bell, D. N.F. and Blanchflower, D. G. (2015). Youth unemployment in Greece: measuring the challenge. IZA Journal of European Labor Studies, 4(1), 71-92.

Blinder, A. S. (2010). Keynesian https://pdfs.semanticscholar.org/1206/12a340d5fbc90914c0998754aa256889fde0.pdf, (Erişim Tarihi: 08.06.2019).

Carrion-I-Silvestre, J. L., Kim, D. and Perron, P. (2009). GLS-Based Unit Root Tests with Multiple Structural Breaks Under Both the Null and The Alternative Hypotheses. Econometric Theory, 25, 1754-1792.

Dünya Bülteni (2011). Hiroşima'ya Giden Yol: Japon Askeri İmparatorluğu. https://www.dunyabulteni.net/tarihdosyasi/hirosima-ya-giden-yol-japon-askeri-imparatorlugu-h169699.html, (Erişim Tarihi: 03.06.2019).

Eğri, T. (2018). İşsizlik ve Ekonomik Çıktı İlişkisi: Mısır için Okun Yasası Analizi. Journal of Yasar University, 13(49), 68-78.

Esmeraldo, X. and Veton, K. (2019). Estimating Okun's Law for Albania (1993 - 2017). https://www.researchgate.net/publication/331802858_Estimating_Okun's_Law_for_Albania_1993_-2017, (Erişim Tarihi: 08.06.2019).

Granger, C.W.J. (1969). Investigating Causal Relations by Econometric Models and Cross-Spectral Methods. Econometrica, 37, 424-438.

Gujarati, D.N. ve Porter, D. (2012). Temel Ekonometri, Çeviren: Ümit Şenesen, Gülay Günlük Şenesen, İstanbul: Literatür Yayıncılık.

Güney, A. (2009). İşsizlik, Nedenleri, Sonuçları ve Mücadele Yöntemleri. Kamu-İ̧̧ İ̧ Hukuku ve İktisat Dergisi, Kamu İşletmeleri İşverenleri Sendikası Yayını, 10(4), 135-159.

Işık, M. ve Öztürk Çetenek, Ö. (2018). İktisadi Hoşnutsuzluk Endeksi Makroekonomik Performansın Ölçülmesinde Başarılı Bir Gösterge midir? Türkiye ve BRICS Ülkeleri Üzerine Bir Değerlendirme. PESA Uluslararası Ekonomik Araştırmalar Dergisi, 4(4), 37-50.

Kigabo, T. R. and Kamanzi, C. (2018). Job Creating Growth and Governance: The Case of Rwanda. East Africa Research Papers in Economics and Finance, EARP-EF No. 2018: 31.

Léautier, F. A. and Hanson, K. T. (2013). Jobless Economic Growth: Lessons From Africa. ACBF Working Paper No. 25 ,

Lester, D. (1996). The Impact of Unemployment on Marriage and Divorce. Journal of Divorce \& Remarriage, 25(34), 151-153.

Levin, E. J. and Wright, R. E. (2002). Unemployment Insurance, Moral Hazard, and Economic Growth. IAER, 8(1), 373-384.

Maki, D. (2012). Tests for Cointegration Allowing for an Unknown Number of Breaks. Economic Modelling, 29(5), 2011-2015.

Máté, D. (2010). A Theoretical and Growth Accounting Approach of Jobless Growth. Periodica Oeconomica, October, $67-76$.

Murat, S. ve Y1lmaz-Eser, B. (2013). Türkiye'de Ekonomik Büyüme ve İstihdam İlişkisi: İstihdam Yaratmayan Büyüme Olgusunun Geçerliliği. HAK-IŞ Uluslararası Emek ve Toplum Dergisi, 2(3), 92-123.

Muratoğlu, Y. (2011). Ekonomik Büyüme ve İşsizlik Arasındaki Asimetrik İlişki ve Türkiye'de Okun Yasasının Sınanması. Hitit Üniversitesi, Sosyal Bilimler Enstitüsü, İktisat Anabilim Dalı, Yayımlanmamış Yüksek Lisans Tezi.

Nazlıoğlu, Ş. (2010). Makro İktisat Politikalarının Tarım Sektörü Üzerindeki Etkileri: Gelişmiş ve Gelişmekte Olan Ülkeler İçin Bir Karşılaştırma. Erciyes Üniversitesi Sosyal Bilimler Enstitüsü Yayımlanmamış Doktora Tezi.

Neely, C. J. (2010). Okun's Law: Output and Unemployment. Federal Reserve Bank of St. Louis Economic Synopses, $4,1-2$. 
O’Kane, K. (2011). La Génération Perdue: Youth Unemployment in France and the Policies Behind it. Senior Honors Projects. Paper 209, https://digitalcommons.uri.edu/cgi/viewcontent.cgi?article=1264\&context=srhonorsprog, (Erişim Tarihi: 05.06.2019).

Okun, A. (1962). Potential GNP: Its Measurement and Significance, American Statistical Association: Proceeding of the Business and Economics Statistics Section.

Özdemir, B. K. ve Yıldırım, S. (2015). Türkiye'de Ekonomik Büyüme ve İstihdam Arasındaki Nedensellik İlişkisinin Analizi: Özçıkarımlı Dalgacık Yaklaşımı. Dumlupınar Üniversitesi Sosyal Bilimler Dergisi, 38, 97-116.

Rashad, J. (2011). The Arab Spring of Discontent A Collection From e-International Relations. https://www.eir.info/wp-content/uploads/arab-spring-collection-e-IR.pdf, (Erişim Tarihi: 05.06.2019).

Sabah (2019). Son dakika: İlk çeyrek büyüme rakamları açıklandı! https://www.sabah.com.tr/apara/haberler/2019/05/31/buyume-rakamlari-aciklandi, (Erişim Tarihi: 07.06.2019).

Shahbaz, M. and Dube, S. (2012). Revisiting the Relationship between Coal Consumption and Economic Growth: Cointegration and Causality Analysis in Pakistan. Applied Econometrics and International Development, 12(1), 165192.

Shin, Y, Yu, B. and Greenwood-Nimmo, M. (2014) Modelling Asymmetric Cointegration and Dynamic Multipliers in a Nonlinear ARDL Framework" Festschrift in Honor of Peter Schmidt: Econometric Methods and Applications, eds. by R. Sickels and W. Horrace: (Springer), 281-314.

Stinespring, J. and Luciene, J. (2019). Okun's Law at the Florida MSA Level. Journal of Applied Business and Economics, 21(1), 131-140.

Stober, E. O. (2015). The Validity of Okun's Law: An Assessment of United Kingdom's Unemployment Output Relationship. International Journal of Economic Practices and Theories, 5(1), 10-15.

Timur, T. ve Doğan, Z. (2015). İstihdam Yaratmayan Büyüme: Türkiye Analizi. Ardahan Üniversitesi İktisadi ve İdari Bilimler Fakültesi Dergisi, 2, 231-247.

Tejani, S. (2016). Jobless Growth in India: An Investigation. Cambridge Journal of Economics, 40, 843-870.

The Economist (2010). Jobless Growth. https://www.economist.com/special-report/2010/06/05/jobless-growth, (Erişim Tarihi: 07.06.2019).

TÜIK $\quad$ (2014). İstatistik Göstergeler 1923-2013. http://www.tuik.gov.tr/Kitap.do?metod=KitapDetay\&KT_ID=0\&KITAP_ID=160, Erişim Tarihi: 07.06.2019).

TÜİK (2019). Temel İstatistikler, İstihdam, İşsizlik ve Ücret, Nüfusun İşü̈cü Durumu, Kurumsal Olmayan Nüfusun İşgücü Durumu. http://www.tuik.gov.tr/UstMenu.do?metod=temelist, (Erişim Tarihi: 07.06.2019).

Uslu, H., (2018). Ekonomik Büyüme ve İşsizlik İlişkisinin Türkiye Ekonomisindeki Yeni Gelişmeler Çerçevesinde İncelenmesi. Social Sciences Studies Journal, 4(20), 1515-1531.

World Bank (2018). Jobless Growth? http://documents.worldbank.org/curated/ en/825921524822907777/pdf/125779PUB-PUBLIC.pdf, (Erişim Tarihi: 07.06.2019).

World Bank (2019). GDP growth https://data.worldbank.org/indicator/NY.GDP.MKTP.KD.ZG?view=chart, (Erişim Tarihi: 07.06.2019).

Yanbaşl1, E. (2014). Türkiye’de Genç İşsizliği Sorunu ve İşsizlikle Mücadelede Uygulanan Ekonomi Politikalarının Analizi. Adnan Menderes Üniversitesi, Sosyal Bilimler Enstitüsü, İktisat Anabilim Dalı, Yayımlanmamış Yüksek Lisans Tezi.

Yazıcı, H. U. (2018). Türkiye'de İşsizlik Ve Ekonomik Büyüme Arasındaki İlişsi (1960-2015). Bartın Üniversitesi, Sosyal Bilimler Enstitüsü, İktisat Anabilim Dalı, Yayımlanmamış Yüksek Lisans Tezi.

Yeldan, E. ve Ercan, H. (2011). Growth, Employment Policies and Economic Linkages: Turkey. International Labour Organization The Employment Working Papers, 84, 1-51.

Yıldırım, K., Karaman, D. ve Taşdemir, S. (2009). Makroekonomi. (8. Baskı). Seçkin Yayınevi, Ankara.

Yüksel, S. (2016). Rusya Ekonomisinde Büyüme, İşsizlik ve Enflasyon Arasındaki Nedensellik İlişkileri. Finans Politik \& Ekonomik Yorumlar, 53(614), 43-57. 


\section{EKLER}

Ek 1: DOLS Yöntemiyle Gerçekleştirilen Regresyon Analizinde Otokorelasyon Sorununun Olmadığına Dair Korelogram Grafiği (1923-1971)

\begin{tabular}{|c|c|c|c|c|c|c|c|c|c|c|}
\hline \multicolumn{3}{|c|}{ Equation: SON } & \multicolumn{6}{|c|}{ Workfile: VERILER_1923-1972::Veriler' } & \multicolumn{2}{|c|}{$\square \square$} \\
\hline View & Proc & Object & Print & Name & Freeze & Estimat & te Fore & cast Stats & $s$ Resids & \\
\hline \multicolumn{11}{|c|}{ Correlogram of Residuals Squared } \\
\hline \multicolumn{11}{|c|}{$\begin{array}{l}\text { Date: } 06 / 12 / 19 \text { Time: } 08: 48 \\
\text { Sample: } 19241971 \\
\text { Included observations: } 29\end{array}$} \\
\hline \multicolumn{3}{|c|}{ Autocorrelation } & \multicolumn{3}{|c|}{ Partial Correlation } & \multicolumn{2}{|r|}{$\mathrm{AC}$} & PAC & \multirow{2}{*}{ Q-Stat } & Prob* $^{*}$ \\
\hline & I & י י & & I & י י & 1 & 0.263 & 0.263 & & 0.136 \\
\hline & 1 & b 1 & & ' & ' & 2 & 0.032 & -0.040 & 2.2574 & 0.323 \\
\hline & I & 曰 ا & & ' & 曰 & 3 & 0.173 & 0.188 & 3.2953 & 0.348 \\
\hline & ' & 曰 & & I & 巨 & 4 & 0.199 & 0.116 & 4.7258 & 0.317 \\
\hline & ' & 曰 & & I & $\mathrm{p}$ & 5 & 0.139 & 0.074 & 5.4448 & 0.364 \\
\hline & I & 1 & & & I & 6 & -0.015 & -0.093 & 5.4534 & 0.487 \\
\hline & ' & 巳 & & ' & 已 & 7 & 0.126 & 0.128 & 6.0990 & 0.528 \\
\hline & 1 & e & & I & ' & 8 & 0.088 & -0.037 & 6.4282 & 0.599 \\
\hline & 1 & p & & 1 & ' & 9 & 0.027 & 0.016 & 6.4598 & 0.693 \\
\hline & 1 문 & I & & $1 \square$ & ' & 10 & -0.157 & -0.224 & 7.6261 & 0.665 \\
\hline & 1 & 1 & & 1 & ' & 11 & -0.074 & 0.001 & 7.9004 & 0.722 \\
\hline & I & I & & 1 & 1 & 12 & 0.039 & -0.005 & 7.9807 & 0.787 \\
\hline
\end{tabular}

Not: Bu grafikte bulgular güven aralığı içinde kaldığg için, yapılan tahminde otokorelasyon sorunu yoktur.

\section{Normal Dağılım Grafiği (1923-1971)}

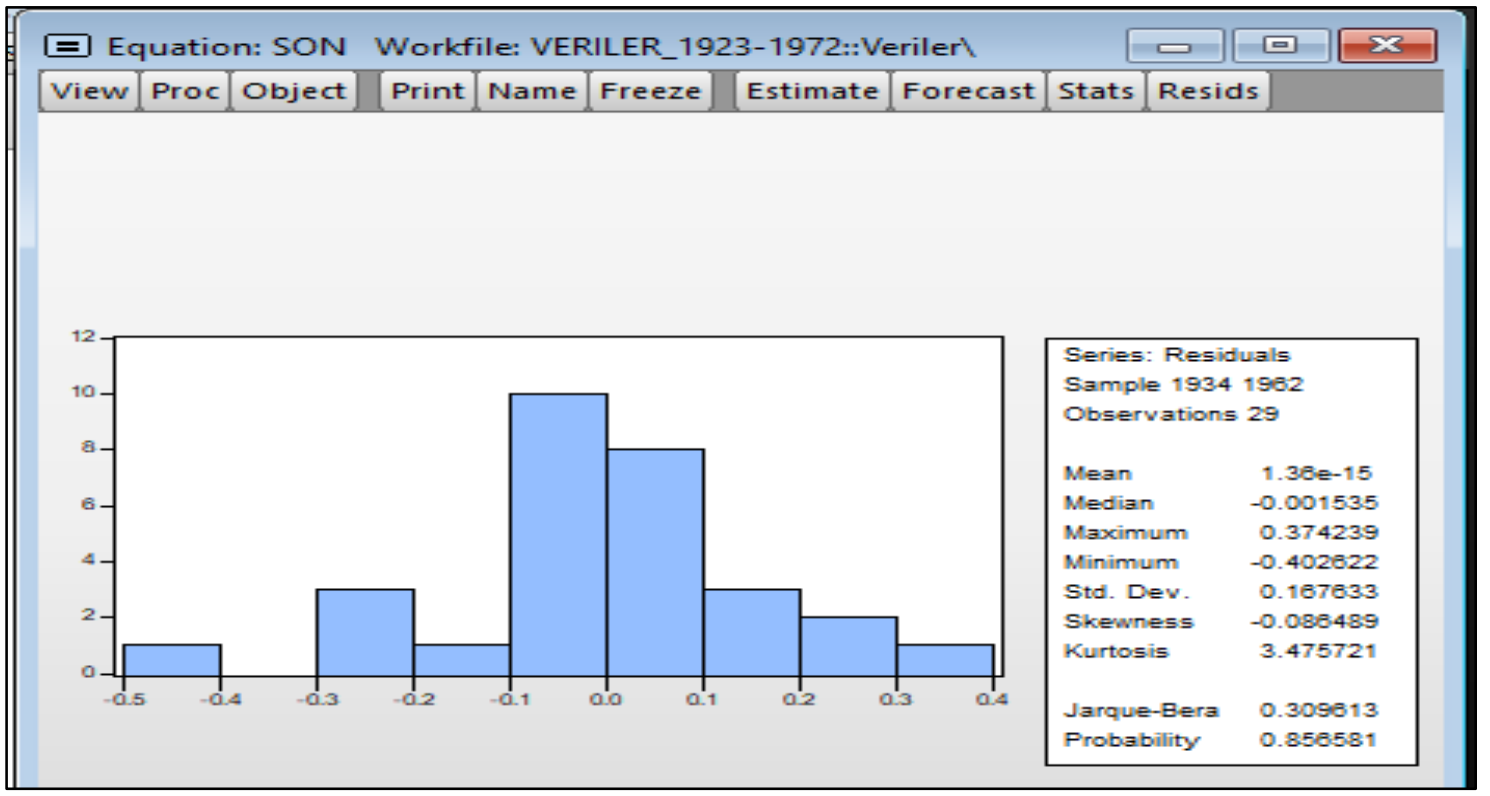

Not: Jarque-Bera testinin olasılık değeri 0.05 'ten büyük olduğu için tahmine ait atıklar normal dağılıma sahiptir. Yapılan tahminler güvenilirdir. 
Ek 2: DOLS Yöntemiyle Gerçekleştirilen Regresyon Analizinde Otokorelasyon Sorununun Olmadığına Dair Korelogram Grafiği (1972-2019)

\begin{tabular}{|c|c|c|c|c|c|c|c|c|c|c|}
\hline \multicolumn{11}{|c|}{ Equation: SON Workfile: VEF } \\
\hline View & Proc] & Object & Print & Name & Freeze & Estimat & te Forec & cast Stats & $s$ Resids & \\
\hline \multicolumn{11}{|c|}{ Correlogram of Residuals Squared } \\
\hline \multicolumn{11}{|c|}{$\begin{array}{l}\text { Date: 06/12/19 Time: } 08: 53 \\
\text { Sample: } 19722019 \\
\text { Included observations: } 31\end{array}$} \\
\hline \multicolumn{3}{|c|}{ Autocorrelation } & \multicolumn{3}{|c|}{ Partial Correlation } & \multicolumn{2}{|r|}{$\mathrm{AC}$} & PAC & \multirow{2}{*}{ Q-Stat } & \multirow{2}{*}{$\frac{\text { Prob* }}{0.929}$} \\
\hline & I & 1 & & $\mathbf{I}$ & I & 1 & -0.015 & -0.015 & & \\
\hline & I & & & ' & I & 2 & -0.011 & -0.011 & 0.0120 & 0.994 \\
\hline & I & 巨 & & I & 巳 & 3 & 0.148 & 0.148 & 0.8155 & 0.846 \\
\hline & I & 1 & & I & 1 & 4 & 0.020 & 0.025 & 0.8309 & 0.934 \\
\hline & & I & & I & I & 5 & -0.082 & -0.081 & 1.0981 & 0.954 \\
\hline & & & & I & I & 6 & 0.082 & 0.059 & 1.3712 & 0.968 \\
\hline & I & 巨 & & I & 曰 & 7 & 0.139 & 0.138 & 2.1908 & 0.949 \\
\hline & 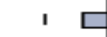 & 1 & & 1 ᄃ & I & 8 & -0.143 & -0.122 & 3.1039 & 0.928 \\
\hline & I & I & & 1 & I & 9 & -0.046 & -0.072 & 3.2010 & 0.956 \\
\hline & I & I & & I & I & 10 & -0.002 & -0.049 & 3.2012 & 0.976 \\
\hline & & & & I & I & 11 & -0.100 & -0.059 & 3.7091 & 0.978 \\
\hline & I & a & & I & י & 12 & 0.088 & 0.130 & 4.1220 & 0.981 \\
\hline & 1 ㄷ & I & & $1 \square$ & I & 13 & -0.150 & -0.193 & 5.3945 & 0.965 \\
\hline & 1 & I & & 1 & I & 14 & 0.001 & 0.013 & 5.3946 & 0.980 \\
\hline & I & I & & 1 & I & 15 & -0.062 & -0.046 & 5.6385 & 0.985 \\
\hline & I & I & & I & I & 16 & -0.048 & -0.015 & 5.7926 & 0.990 \\
\hline
\end{tabular}

Not: Bu grafikte bulgular güven aralığı içinde kaldığı için, yapılan tahminde otokorelasyon sorunu yoktur.

\section{Normal Dağılım Grafiği (1972-2019)}

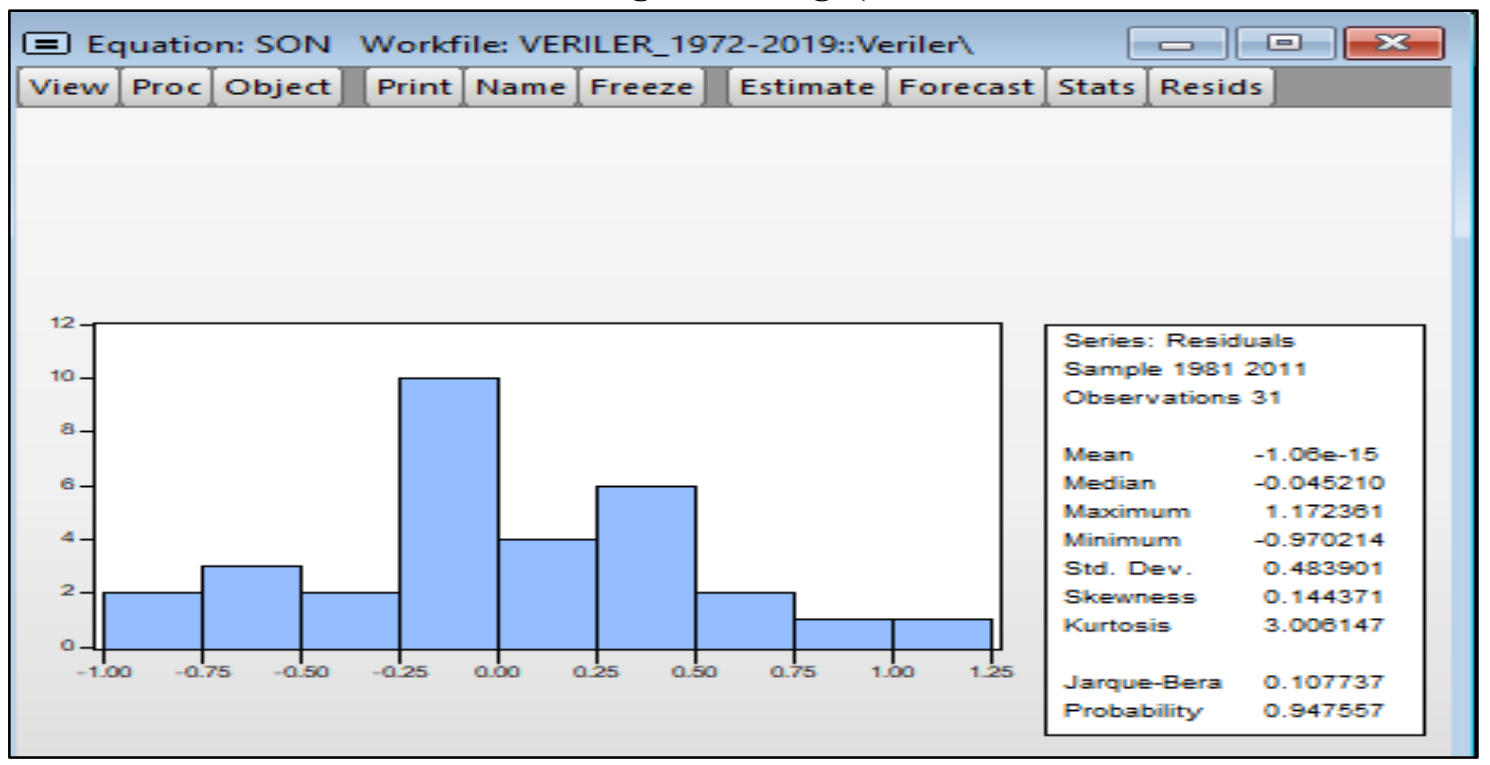

Not: Jarque-Bera testinin olasılık değeri 0.05 'ten büyük olduğu için tahmine ait atıklar normal dağılıma sahiptir. Yapılan tahminler güvenilirdir. 
Ek 3: DOLS Yöntemiyle Gerçekleştirilen Regresyon Analizinde Otokorelasyon Sorununun Olmadığına Dair Korelogram Grafiğgi (1923-2019)

\begin{tabular}{|c|c|c|c|c|c|c|c|c|c|c|}
\hline \multicolumn{9}{|c|}{ E Equation: SON Workfile: VERILER_1923-2019::Veriler } & \multicolumn{2}{|c|}{$\square \quad \square \quad x$} \\
\hline View & Proc & Object & Print & Name & Freeze & Estimate & Fore & cast Stats & s Resids & \\
\hline \multicolumn{11}{|c|}{ Correlogram of Residuals Squared } \\
\hline \multicolumn{11}{|c|}{$\begin{array}{l}\text { Date: 06/12/19 Time: 08:55 } \\
\text { Sample: } 19242019 \\
\text { Included observations: } 94\end{array}$} \\
\hline \multicolumn{3}{|c|}{ Autocorrelation } & \multicolumn{3}{|c|}{ Partial Correlation } & \multicolumn{2}{|r|}{$\mathrm{AC}$} & PAC & Q-Stat & Prob* \\
\hline & 1 & 口 & & 1 & 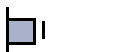 & 1 & 0.170 & 0.170 & 2.8158 & 0.093 \\
\hline & 1 & b 1 & & 1 & 1 & 20 & 0.063 & 0.035 & 3.2087 & 0.201 \\
\hline & 1 & 1 & & 1 & 1 & $3-c$ & 0.012 & -0.029 & 3.2226 & 0.359 \\
\hline & 1 & 1 & & 1 & 1 & $4-c$ & 0.016 & -0.012 & 3.2477 & 0.517 \\
\hline & 1 & 1 & & 1 & 1 & 5 & 0.006 & 0.013 & 3.2515 & 0.661 \\
\hline & 1 & 1 & & 1 & 1 & $6-($ & 0.019 & -0.022 & 3.2897 & 0.772 \\
\hline & 1 & 1 & & 1 & I & 7 & 0.013 & 0.019 & 3.3077 & 0.855 \\
\hline
\end{tabular}

Not: Bu grafikte bulgular güven aralığı içinde kaldığg için, yapılan tahminde otokorelasyon sorunu yoktur.

\section{Normal Dağılım Grafiği (1923-2019)}

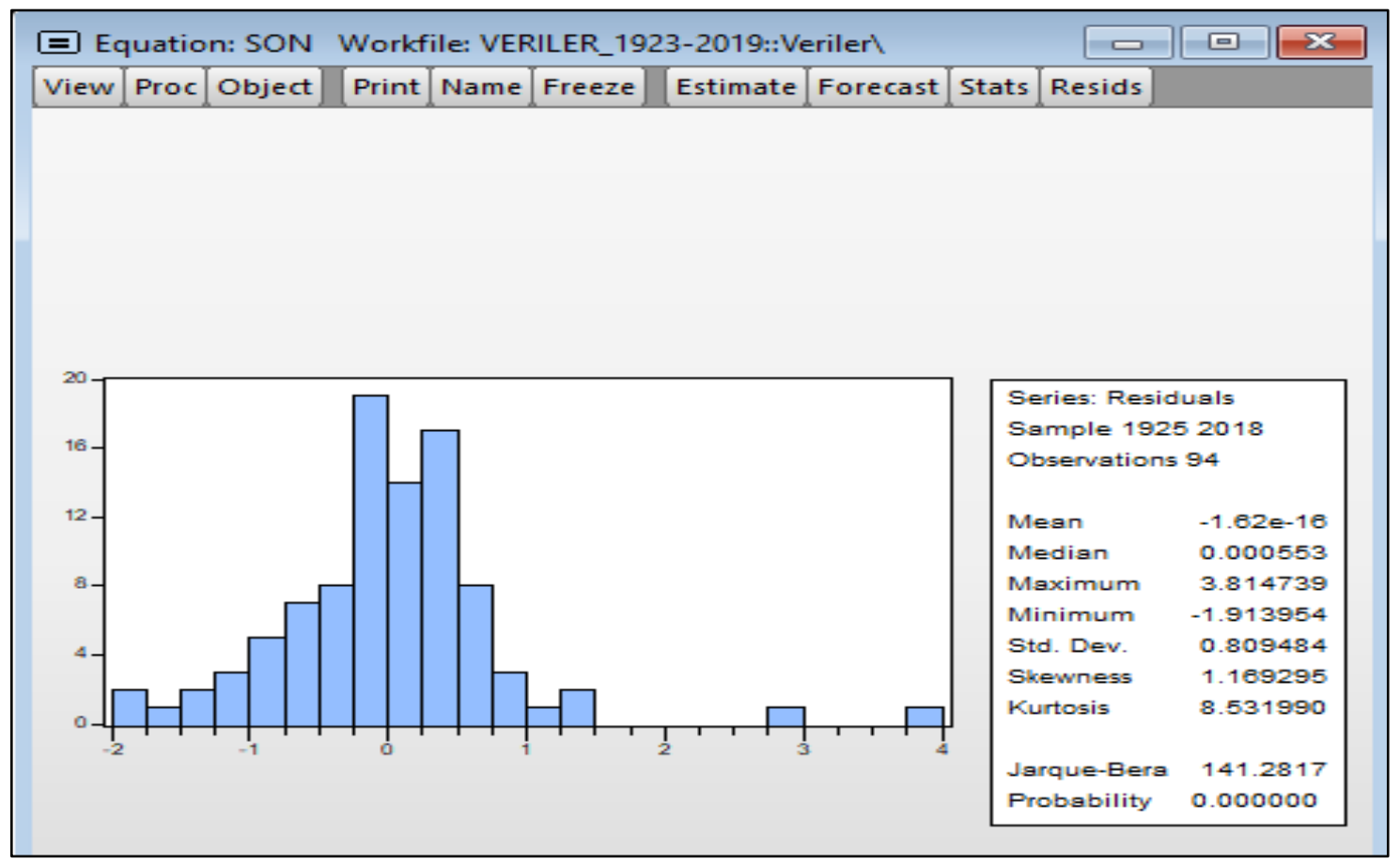

Not: Jarque-Bera testinin olasılık değeri 0.05 'ten küçük olduğu için tahmine ait atıklar normal dağılıma sahip değildir. 
Ek 4: Optimum Gecikme Uzunluğu Belirleme İşlemi Sonuçları (1923-1971 Dönemi)

VAR Lag Order Selection Criteria

Endogenous variables: DU DG

Exogenous variables: $\mathrm{C}$

Date: 08/06/19 Time: 12:35

Sample: 19241971

Included observations: 42

\begin{tabular}{cccllll}
\hline $\boldsymbol{L a g}$ & $\boldsymbol{L} \boldsymbol{L g} \boldsymbol{L}$ & $\boldsymbol{L R}$ & $\boldsymbol{F P E}$ & $\boldsymbol{A I C}$ & $\boldsymbol{S C}$ & $\boldsymbol{H Q}$ \\
0 & -200.8867 & NA & 53.81407 & 9.661271 & 9.744017 & 9.691601 \\
1 & -187.3909 & 25.06358 & 34.25473 & 9.209091 & $9.457330^{*}$ & 9.300081 \\
2 & -183.5467 & 6.773081 & 34.57138 & 9.216511 & 9.630242 & 9.368160 \\
3 & -179.0045 & 7.570411 & 33.82546 & 9.190690 & 9.769913 & 9.402998 \\
$\mathbf{4}$ & $\mathbf{- 1 6 6 . 7 2 1 6}$ & $\mathbf{1 9 . 3 0 1 7 3}^{*}$ & $\mathbf{2 2 . 9 6 5 7 6 *}$ & $\mathbf{8 . 7 9 6 2 6 5 *}$ & $\mathbf{9 . 5 4 0 9 8 1}$ & $\mathbf{9 . 0 6 9 2 3 3}$ \\
5 & -165.6330 & 1.606923 & 26.68606 & 8.934905 & 9.845113 & 9.268532 \\
\hline
\end{tabular}

$*$ indicates lag order selected by the criterion

LR: sequential modified LR test statistic (each test at 5\% level)

FPE: Final prediction error

AIC: Akaike information criterion

SC: Schwarz information criterion

HQ: Hannan-Quinn information criterion

Not: 1923-1971 dönemi için optimum gecikme uzunluğunun (4) olduğuna karar verilmiştir. (4) Gecikmeli VAR modelinin istikrarlı olduğuna dair ters karakteristik kökler grafiği aşağıda sunulmuştur.

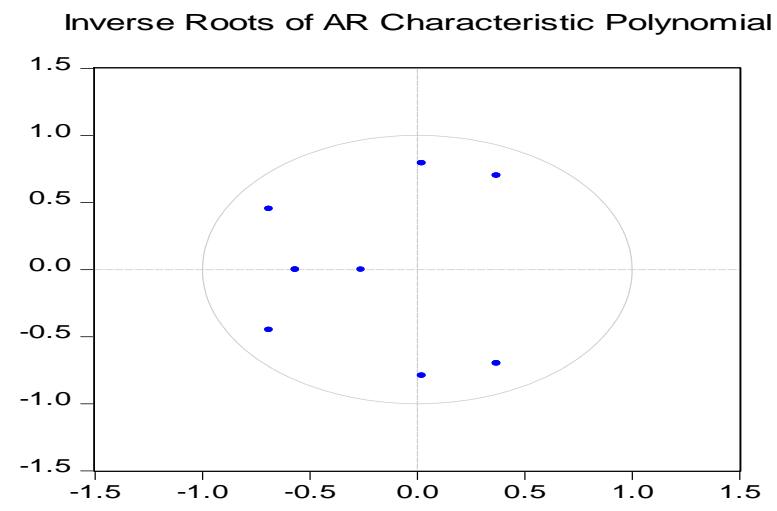

Not: Yandaki grafikte ters karakteristik kökler birim çember içinde kaldığı için (4) gecikmeli VAR modeli istikrarlıdır. (4) Gecikmeli VAR modelinde otokorelasyon ve değişen varyans sorunun varlığına ilişkin test sonuçları aşağıda yer almaktadır:

\begin{tabular}{lccc}
\hline & Test & Olasılık & Karar \\
& İstatistiği & Değeri & \\
LM Otokorelasyon Testi & 0.72 & 0.13 & Otokorelasyon Sorunu Yok \\
Değişen Varyans Testi & 56.67 & 0.18 & Değişen Varyans Sorunu Yok \\
\hline Not: Bu sonuçlara göre (4) gecikmeli VAR modeli ve bu modele dayanarak gerçekleştirilecek \\
nedensellik testi sonuçları güvenilir olacaktır.
\end{tabular}


Ek 5: Optimum Gecikme Uzunluğu Belirleme Sonuçları (1972-2019 Dönemi)

VAR Lag Order Selection Criteria

Endogenous variables: DU DG

Exogenous variables: $\mathrm{C}$

Date: 08/06/19 Time: $12: 46$

Sample: 19722019

Included observations: 43

\begin{tabular}{cccllll}
\hline Lag & $\boldsymbol{L o g} \boldsymbol{L}$ & $\boldsymbol{L R}$ & $\boldsymbol{F P E}$ & $\boldsymbol{A I C}$ & $\boldsymbol{S C}$ & $\boldsymbol{H} \boldsymbol{Q}$ \\
0 & -213.8007 & $\mathrm{NA}$ & 78.37499 & 10.03724 & 10.11916 & 10.06745 \\
1 & -205.1313 & $16.12904 *$ & 63.10265 & 9.820063 & $10.06581 *$ & $9.910687 *$ \\
2 & -201.0282 & 7.252165 & $\mathbf{6 2 . 9 0 4 7 8}$ & 9.815263 & 10.22484 & 9.966304 \\
$\mathbf{3}$ & $\mathbf{- 1 9 6 . 7 8 8 0}$ & $\mathbf{7 . 0 9 9 7 7 7}$ & $\mathbf{6 2 . 4 3 8 6 5 *}$ & $\mathbf{9 . 8 0 4 0 9 3} *$ & $\mathbf{1 0 . 3 7 7 5 1}$ & $\mathbf{1 0 . 0 1 5 5 5}$ \\
4 & -194.5782 & 3.494563 & $\mathbf{6 8 . 3 1 7 2 0}$ & 9.887359 & 10.62461 & 10.15923 \\
\hline
\end{tabular}

* indicates lag order selected by the criterion

LR: sequential modified LR test statistic (each test at 5\% level)

FPE: Final prediction error

AIC: Akaike information criterion

SC: Schwarz information criterion

HQ: Hannan-Quinn information criterion

Not: Bu tabloya göre optimum gecikme uzunluğu (3)'tür. (3) Gecikmeli VAR modelinin istikrarlı olduğuna dair ters karakteristik kökler grafiği aşağıda sunulmuştur.

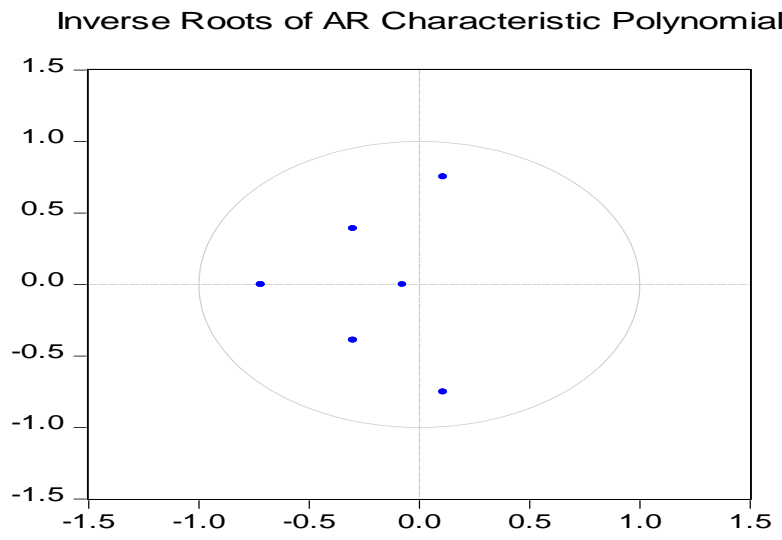

Not: Yandaki grafikte ters karakteristik kökler birim çember içinde kaldığ için (3) gecikmeli VAR modeli istikrarlıdır. (3) Gecikmeli VAR modelinde otokorelasyon ve değişen varyans sorunun varlığına ilişkin test sonuçları aşağıda yer almaktadir:

\begin{tabular}{lccl}
\hline & Test İstatistiği & Olasılık Değeri & Karar \\
LM Otokorelasyon Testi & 1.04 & 0.39 & Otokorelasyon Sorunu Yok \\
Değişen Varyans Testi & 40.88 & 0.26 & Değişen Varyans Sorunu Yok \\
\hline
\end{tabular}

Not: Bu sonuçlara göre (3) gecikmeli VAR modeli ve bu modele dayanarak gerçekleştirilecek nedensellik testi sonuçları güvenilir olacaktır. 
Ek 6: Optimum Gecikme Uzunluğu Belirleme Sonuçları (1923-2019 Dönemi)

VAR Lag Order Selection Criteria

Endogenous variables: DU DG

Exogenous variables: C ECT(-1)

Date: 08/06/19 Time: 12:55

Sample: 19242019

Included observations: 90

\begin{tabular}{cccllll}
\hline $\boldsymbol{L a g}$ & $\boldsymbol{L} \boldsymbol{\operatorname { o g } \boldsymbol { L }}$ & $\boldsymbol{L R}$ & $\boldsymbol{F P E}$ & $\boldsymbol{A I C}$ & $\boldsymbol{S} \boldsymbol{C}$ & $\boldsymbol{H Q}$ \\
0 & -451.7286 & $\mathrm{NA}$ & 85.76081 & 10.12730 & 10.23840 & 10.17210 \\
1 & -432.9465 & 35.89457 & 61.75499 & 9.798812 & $10.02102 *$ & 9.888418 \\
2 & -426.3511 & 12.31154 & 58.31018 & 9.741135 & 10.07444 & $9.875544 *$ \\
3 & -422.4082 & 7.184680 & 58.41615 & 9.742406 & 10.18682 & 9.921618 \\
$\mathbf{4}$ & $\mathbf{- 4 1 5 . 3 4 9 0}$ & $\mathbf{1 2 . 5 4 9 8 2} *$ & $\mathbf{5 4 . 6 2 6 0 2} *$ & $\mathbf{9 . 6 7 4 4 2 2} *$ & $\mathbf{1 0 . 2 2 9 9 3}$ & $\mathbf{9 . 8 9 8 4 3 7}$ \\
5 & -414.6352 & 1.237159 & $\mathbf{5 8 . 8 4 4 0 1}$ & 9.747450 & 10.41407 & 10.01627 \\
\hline
\end{tabular}

* indicates lag order selected by the criterion

LR: sequential modified LR test statistic (each test at 5\% level)

FPE: Final prediction error

AIC: Akaike information criterion

SC: Schwarz information criterion

HQ: Hannan-Quinn information criterion

Not: Bu tabloya göre; 1923-2019 dönemi için gerçekleştirilecek nedensellik analizinde optimum gecikme uzunluğunun (4) olarak alınması gerektiğine karar verilmiştir. (4) Gecikmeli VAR modelinin istikrarlı olduğuna dair ters karakteristik kökler grafiği aşağıda sunulmuştur.

Inverse Roots of AR Characteristic Polynomial

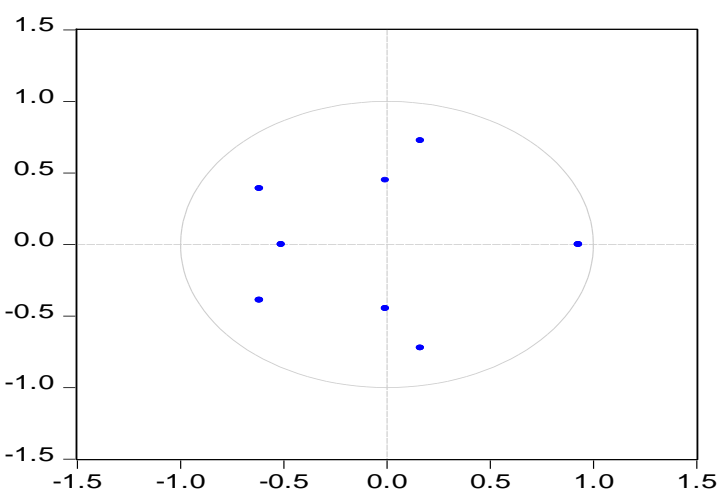

Not: Yandaki grafikte ters karakteristik kökler birim çember içinde kaldığ 1 için (4) gecikmeli VAR modeli istikrarlıdır. (4) Gecikmeli VAR modelinde otokorelasyon ve değişen varyans sorunun varlığına ilişkin test sonuçları aşağıda yer almaktadır.

\begin{tabular}{lcccl}
\hline LM & Otokorelasyon & Test İstatistiği & Olasılık Değeri & Karar \\
Testi & 2.32 & 0.058 & Otokorelasyon Sorunu Yok \\
Değişen Varyans Testi & 29.30 & 0.99 & Değişen Varyans Sorunu Yok \\
\hline
\end{tabular}

Not: Bu sonuçlara göre (4) gecikmeli VAR modeli ve bu modele dayanarak gerçekleştirilecek nedensellik testi sonuçları güvenilir olacaktır. 


\section{Extended Summary}

\section{Jobless Economic Growth: An Econometric Analysis for Turkey in the Framework of Okun Law}

Economic growth is one of the most important economic phenomena that increases income in countries, reduces unemployment in general and increases the welfare level of citizens. Decreases in economic growth bring together poverty and low welfare levels in countries by reducing employment and national income per capita. When this situation persists for a long time, moral depression, divorces, crime and suicides may increase and social explosions may occur. Therefore, reducing unemployment is of great importance.

In the theory developed by Okun (1962); it is expected that economic growth above the average growth rate will reduce unemployment in countries. There are many empirical studies supporting this theory in the literature.

In recent years, however, it has been discussed that there are cases in which the Okun Law does not apply in every country, in all periods, and in spite of increasing economic growth, unemployment does not diminish. This case is clearly experienced in Turkey's economy in the 2010-2011 period and began to be discussed among researchers. In Turkey, despite 8.5\% growth in 2010 and $11 \%$ growth in 2011, expected reduction in the unemployment rate which significantly increased in 2008 crisis could not be achieved. Similar phenomena remained on the agenda in 2013 , when the economy grew by $8.5 \%$ and in 2017 , when it grew by $7.4 \%$. Although economic growth continued in 2018, the unemployment rate increased from $11 \%$ to $14.7 \%$. Therefore; it became necessary to examine the validity of Okun Law and jobless economic growth in Turkey's economy in detail covering a long period of time. The main motivation of this study is this need.

In the study; the relationships between the unemployment rate and economic growth are analyzed in detail from 1923, the establishment of the Republic of Turkey, to the beginning of 2019 as a whole and with two sub-periods. The basic hypothesis tested in the study is whether the economic growth above the average decreases the unemployment rate. The main purpose of the stud is to put out the real situation between the unemployment rate and economic growth in Turkey and is to develop policy recommendations on how to reduce unemployment.

In the study, economic growth and unemployment data for the period of 1923-2019 compiled from TURKSTAT, EVDS and World Bank are used. Analyses are performed separately for 1923-1971, 1972-2019 and 1923-2019 periods and the findings are compared.

As the period of analysis is long and many events affected Turkey's economy closely during this period, stationarity of the series is investigated by Carrion-i-Silvestre et al. (2009) unit root test with multiple structural breaks and the existence of cointegration relationships between the series is examined by Maki (2012) cointegration test with multiple structural breaks. The structural break dates in the cointegration vector determined By Maki (2012) cointegration test are included in the regression analysis with dummy variables. Regression analyzes are performed with DOLS, FMOLS and CCR methods.

Since the cointegration relationship is determined in the model, the existence of causality relationships between the series is analyzed by causality test based on the Vector Error Correction Model (VECM).

At the analysis; it is determined that all series are I(1) and there is a cointegration relationship between the series. According to regression analysis; it is seen that Okun Law is strongly valid in the 1923-1971 period in Turkey's economy and weakly valid in the 1923-2019 period, while Jobless Economic Growth Theory is found to be valid for the 1972-2019 period. 
Accordingly, every $1 \%$ economic growth above 5.3\% in the 1923-1971 period decreased the unemployment rate by $0.33 \%$ and every $1 \%$ economic growth above $4.9 \%$ in the $1923-2019$ decreased the unemployment rate by $0.03 \%$ units. In the $1972-2019$ period, each $1 \%$ economic growth above $4.4 \%$ increased unemployment by $0.63 \%$.

According to VECM causality test; between the unemployment rate and economic growth in Turkey's economy, no causality relationships can be estimated in the short term while long-term causality relationships are determined.

Based on the findings obtained from this study; in order to reduce unemployment in Turkey, economic growth alone is not enough and other policy tools are needed. The rate of population growth and migration flows in the country must be taken under control. In order to increase employment; it is considered that it would be beneficial to reduce the tax and premium burdens on employers and to look for ways to attract more foreign direct investment to the country. 